\title{
An Integrated Bargaining Solution Analysis for Vertical Cooperative Sales Promotion Campaigns Based on the Win-Win-Win Papakonstantinidis Model
}

\author{
George S. Spais, Independent Consultant \& Researcher, Hellenic Open University, Greece
}

\begin{abstract}
Author's intention was to examine the possibility to investigate win-win-win papakonstantinidis model in order to develop an integrated bargaining solution analysis for vertical cooperative sales promotion campaigns. Based on previous theoretical extensions (Spais and Papakonstantinidis, 2011; Spais, Papakonstantinidis and Papakonstantinidis, 2009), this study presented an integrated bargaining solution analysis for cases of optimal allocation of a promotion budget in a cooperative sales promotion campaign in vertical marketing channels. This integrated bargaining solution analysis included: a) three (3) adjusted utility functions, considering the parameters of sales response budgeting method, the break-even sales analysis and the marketing channel member's trade promotion goals; b) the referee solution, the optimal solution for the "three players" and the constraints; c) the definition of the third win in terms of a continuous sensitization process and perfect information; and d) the presentation of the potential outputs from a bargaining process regarding to the sharing of the cooperative sales promotion cost among " $A$ ", " $B$ " and " $C$ " parties/players for different sales promotion offerings. Encouragingly, the review of the modern literature and the four (4) critical case studies of cooperative marketing programs confirmed the need for a win-win-win approach in cooperative sales promotion planning in vertical marketing channels.
\end{abstract}

Keywords: Cooperative Advertising; Cooperative Sales Promotion Campaign; Bargaining Solution Analysis; WinWin-Win Papakonstantinidis Model

\section{INTRODUCTION}

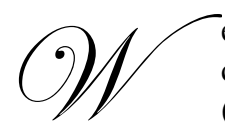

e strongly believe that the well known frameworks for the study of a cooperative marketing campaign process by Fux, Mathieu and Myrach (2007), Merzenich (2005), Schumacher and Meyer (2004) may be seriously considered in order to study cooperative promotion management campaign process in vertical marketing channels in both planning and coordination level. AMA Dictionary (http://www.marketingpower.com/_layouts/Dictionary.aspx?dLetter=V) lists the term "vertical cooperative advertising", (which seems to be used in the broader sense for all promotional activities), defining that it is the advertising in which the retailer and other previous marketing channel members (e.g., manufacturers or wholesalers) share the cost. Yan (2010) argued that cooperative promotion plays a strategically important role in marketing programs. Very close to Yan thesis, He, Prasad and Sethi (2009) underlined that cooperative promotion is an important instrument for aligning manufacturer and retailer decisions in marketing channels. On the other hand, bargaining seems to be critical for marketing channel coordination, e.g., for vertical cooperative promotion (Ailawadi et al., 2009; Huang, Li \& Mahajan, 2002) or resolving channel member conflicts as well as for setting trade terms such as transfer special prices and margins, according to Coughlan et al. (2001). There is a significant literature on constructs such as bargaining problem (Xie \& Wei, 2009) and tendency to conflict (Zhuang, Herndon \& Zhou, 2005). In contrast, the normative and behavioral principles governing marketing channel dependency and coordination regarding the tendency to sovereignty, tendency to improvement and mistrust are relatively unexplored. 
Encouragingly, as the literature reaffirms the critical role of bargaining in marketing channels (Coughlan et al., 2001), we strongly believe that the Papakonstantinidis win-win-win conceptualization as a bargaining solution analysis will receive a significant attention in the marketing literature in the nearest future.

According to Yan (2010), Huang, Li and Mahajan (2002), Li et al. (2002), Huang and Li (2001), cooperative advertising has been used by many industries for decades and continues to play a key promotional role for many manufacturers, retailers and retail customers. According to He et al. (2011), more than $\$ 25$ billion was spent on cooperative advertising in the USA in 2007 compared to the total expenditures in 2000 that were estimated at $\$ 15$ billion and $\$ 900$ million in 1970 - nearly a four-fold increase in real terms and approximately $25 \%-40 \%$ of all manufacturers used this arrangement (SeyedEsfahani, Biazaran and Gharakhan, 2011; Nagler, 2006), The above evidence can be seriously considered in nowadays, if we monitor the latest trends in the media business, where many leaders of the media market characterize the cooperative advertising as the fastest growing category in media business. The successful case of the "MNG's co-op contest" and its alliance with MultiAd Recas (MNG/Media New Group, one of the largest newspaper companies of USA) proves the above (see 346\% increase from cooperative advertising sales in comparison with the previous year), considering that many media companies are struggling to find revenue solutions during this period of economic recession. This increase in spending volume and the overall increase in the significance of cooperative advertising seems to motivate scholars, researchers, authors and thinkers, globally to explore more the role and use of cooperative advertising in practice, the last years.

Although literature clearly shows the raising issue of reinforcing customers' participation in marketing management activities of customer-centric organizations (such as: idea generation, idea screening, concept development and testing, process design, test marketing, building promotion campaigns etc.), (e.g. Awa, 2010; Hu, Jianyou \& Na, 2010; Fang, 2008; Payne, Storbacka \& Frow, 2008; Chen \& Lu, 2007; Etgar, 2007; Lusch, Vargo \& O'Brien, 2007; Galbraith, 2005; Hip \& Grupp, 2005; Piller, 2005; Alam, 2002; Wind \& Rangaswamy, 2001; Sheth, Sisodia \& Sharma, 2000; Johne \& Storey, 1998; Sundbo, 1997; Youngdahl \& Kellogg, 1997; Wilkstrom, 1995; Dabholkar, 1990; Bowen, 1986; Lovelock \& Young, 1979) unfortunately there is no theoretical framework including the customer (as a "third party" or "third player") in a cooperative marketing or promotion planning process. The concept of including the third party, as the third "win" in a traditional "win-win" approach for cooperative marketing and promotion campaigns was presented for the first time in the marketing literature in 2009 (Spais, Papakonstantinidis \& Papakonstantinidis, 2009).

\section{Research aim, initial assumption and research question}

The intention is to examine the possibility to investigate win-win-win papakonstantinidis model in order to develop an integrated bargaining solution analysis for vertical cooperative sales promotion campaigns. Based on previous theoretical extensions (Spais \& Papakonstantinidis, 2011; Spais, Papakonstantinidis \& Papakonstantinidis, 2009), this study will present an integrated bargaining solution analysis for cases of optimal allocation of a promotion budget in a cooperative sales promotion campaign in vertical marketing channels. This integrated bargaining solution analysis will include: a) adjusted utility functions, considering the parameters of sales response budgeting method, the break-even sales analysis and the marketing channel member's trade promotion goals; $b$ ) the referee solution, the optimal solution for the "three players" and the constraints; c) the definition of the third win in terms of a continuous sensitization process and perfect information; $d$ ) the presentation of the potential outputs from a bargaining process regarding to the sharing of the cooperative sales promotion cost among " $\mathrm{A}$ ", " $\mathrm{B}$ " and " $\mathrm{C}$ " parties/players for different sales promotion offerings; and e) the "sensitized game" in order to deepen understanding of the bargaining characteristics. The basic initial assumption of this study is that different problems met in cooperative promotion planning requires adjusted bargaining solution analyses based on the win-win-win approach (including the "third win" for customers) and should not based on the traditional win-win.

According to the available empirical evidence, the SMEs seem to be oriented to the Sales School rather than the Communication School regarding to the goals of promotion campaigns (Vrontis, Thrassou \& Czinkota, 2011; Tsiotsou, Rigopoulou \& Kehagias, 2010; Bazini, 2008; Demetriou, 2008; Elmazi \& Bazini, 2008; Thrassou \& Vrontis, 2006; Huang \& Brown, 1999) and sales response budgeting method seems that becomes quite popular (Akanbi \& Adeyeye, 2011; Du, Hu \& Ai, 2007; Miller \& Pazgal, 2007; Thrassou \& Vrontis, 2006; Little, 2004; Luxton, Hodge \& Reid, 2002). Based on the above, the research question is if the integrated bargaining solution 
analysis of the upgraded 'win-win-win spais-papakonstantinidis-papakonstantinidis' model can be proven of high theoretical and practical value for the understanding and implementation of such analysis for vertical cooperative sales promotion management decisions?

\section{THEORETICAL AND CONCEPTUAL FRAMEWORK}

The win-win-win papakonstantinidis model is a methodological tool for conflict resolution, especially in the case of decision-making, or in forming "instant reflection winning strategies" the BARGAIN (which is the frame). For the needs of the study, we adjust the conceptualization, in order to deal with the development of vertical cooperative promotion management decisions. It has to prove that building a strong competitive advantage in a market mainly depends on the trust links among the partnerships in the vertical marketing channels.

Cohesion in partnership in the supply chain may be measured by the diversification Rate $\left(\mathrm{R}^{*}\right)$ from strict rules: from this point of view, customers intervention should be useful, so as to diversify these "rules" at customized level adjusting them to their needs, wants, consuming identity, including communication codes, customs, ethics, culture. The win-win-win methodology, as a marketing channels' development model, should facilitate customers to "readjust" bargaining rules in each market, through a sensitization process: Customers are defined as a discrete spatial/cultural entity at its sensitization process' limit.

\section{Definitions and assumptions}

Win-win perception: It is based on when each side of a dispute feels they have won. Since both sides benefit from such a scenario, any resolutions to the conflict are likely to be accepted voluntarily. The process of integrative bargaining aims to achieve, through cooperation, win-win outcomes.

Win-win-win perception: It is based on the assumptions of information accessibility and diffusion that characterize the modern globalized societies as well as the complexity in the decision-making values that the "third win" (the "C" factor) could unlock a series of obstacles. Another assumption is that the individual (although his/her doubts) must believe that there is a "third" distinguishable part in the bargain (based on behaviorist analysis through the "neural networks"). Sensitization is introduced (regarding the integrated information) as a main variable of the bargain (the "third invisible part of the negotiation"/ the "C" factor). Sensitization" may concerned as information, thus changed the 2 parts imperfect information, into a complete information as Harsanyi's (1973) conditional probabilities claims. It is about an encephalic hard process in the bargain, which smoothes the angles of conflict or the shares/utilities (according to Nash).The "third win" functions as an umbrella, which conjoins different "dipolar relationships". Especially, in the business context, it must be understood that the existence of a "distinguishable entity", depends upon the degree of understanding and sensitization of knowing better the other polar (the partnerships in a supply chain), even through pecuniary values.

Bargaining problem. A two-person bargaining situation involves two individuals (Von Neuman \& Morgenstern, 1947), who have the opportunity, either to be competitors to each - other (win-lose), or to make coalitions, or even to create pure individual strategies, based on bargainers' instant reflection behavior (win-win) (Crawford, 1997; Aumann, 1987; Arrow \& Debreu, 1954; Nash, 1950). Nash (1951) focused on payoff shares/utilities combination. Bargain may result in either agreement or disagreement (Nash, Nasar \& Kuhn, 2001). Utility expresses the constraint or the "fear factor" of disagreement for the negotiator who desires negotiations to be led in agreement more than the other one. Who needs more, negotiation leading to an agreement expects more utility, but - probably there is a loss in terms of "shares", due to lack of risk. On the contrary, who is indifferent about "agreement" or expects less utility per unit, has- to win in "shares" under the dogma "the more risk, the more profit" (Crawford, 1997). So, bargaining problem is mainly based on "Utility Theory" - a mathematical theory of the Neoclassical School of Thought, able to explain (satisfactory) the individual expectations/anticipations, of a possible outcome. Usually, it is expressed in the form of a mathematical function: $f(u)=u^{1 / 2}$. Individual winning strategies are corresponding 1-1 to utilities U (A) and U (B) (Chun \& Thomson, 1990). Utility theory of the individual is mainly based on the "concept of anticipation". In the "two-person utility theory", two (2) individuals in a bargain have the opportunity to collaborate for mutual benefit in more than one way. In its simple/initial version, no action, taken by one of the two individuals without the consent of the other can affect the well-being of the other one, but in real terms, there is only ONE decision, taken by the individual involved in a bargain. 
Tendency to conflict. Refers to the tendency to competition between the two parts of the bargain with different expectations and controversial interests, results from the combination of: a) the case of the distinguishable entity, b) mistrust of each distinguishable entity, and c) the tendency to improvement. Based on the above, the motive of individual benefit leads with mathematic precision to the conflict, the tendency to sovereignty and from there to a competition climate, which is the corner stone of our economic system.

Tendency to sovereignty. The reason for which it is repeated is stressing the importance of "the need" for sovereignty, which finally "shapes" the expectations. Therefore, we have the following paradox: the expectation determines the motive (individual benefit, sovereignty, competition etc.) and simultaneously "is determined" by the internal need of dominance-sovereignty, something that characterizes our natural world.

Mistrust of each distinguishable entity. Deals with the intentions of the other. Two distinguishable entities have different expectations; otherwise, the expectation of each one would be identified with the expectation of the other. Therefore, there would not be a bargaining and, of course, no "conflict" and no "distinguishable entities". If we had two "players" with precisely opposite interests and expectations, then the (A) would doubt the intentions of (B) and (B) would doubt the intentions of (A), (the "never-ending circle of expectations" by Varoufakis, 2001).

According to Papakonstantinidis $(2011 ; 2007 ; 2004 a ; 2004 b ; 2003 ; 2002)$ and the updated conditions by Spais and Papakonstantinidis (2011), describing the bargaining situations of the win-win-win papakonstantinidis model in cooperative sales promotion campaigns are summarized in Table 1:

Table 1: The assumptions of the win-win-win spais-papakonstantinidis model

1. In a bargaining situation, there are two distinguishable entities with different perceptions, attitudes, expectations and interests. These distinguishable entities, with different expectations, should be motivated (for individual benefit), so that they are activated and they transform the opposite expectations in opposite interests and from there in opposite "strategies of victory, or sovereignty".

2. Tendency sovereignty and the tendency of conflict are strengthened because of the bargaining problems and according to the theory only a "third win" (the "C" factor: the customer) could unlock these series of obstacles. The win-win-win theoretical model suggests that information accessibility and diffusion is crucial because of the relation between knowledge and behavior (the "interaction on bargain-behavior"). The different examples of knowledge types' synthesis and the resulted 1-1 behavior may lead brand manufacturers to understand the bargain-behavior assumption, based on information given. From the other hand, brand manufacturers' information may be the dominant result of this cross-related knowledge types: socialization, sensitization, externalization etc.. Thus, the hypothesis of bargain-behavior interaction is very important in building the suggested " $\mathrm{C}$ Factor" following the Harsanyi's Bayesian Theorem original game can be replaced by a game "where nature first conducts a lottery in accordance with the basic probability distribution" (Harsanyi, 1967). This extension is mainly based on the "Harsanyi's transformation", with a difference: original bargain between two can be replaced by a game, where the $\mathrm{C}$ Factor first conducts a lottery in accordance with the basic probability distribution. In addition, the "C" factor should be seen as the result of a "new" suggested bargaining behavior, coming from sensitization process. In such a context, the $\mathrm{C}$ party/player is given in terms of a continuous sensitization process, tending to sensitization itself, inside the customers. The heart of the analysis for a bargaining solution in a cooperative promotion campaign must be the configuration of how the "sensitized game" $\left(\mathrm{G}^{* *}\right)$ is formed and developed.
3. The "C" party/player (for customers) produces a new behavioral type that converges the interests of both sides. By converting a binomial distribution ( $p, 1-p)$ into a trinomial distribution, (p1, p2 and 1-p1-p2) combined with 3 utility function "prices".

4. Interaction on bargain-behavior is one of the prevailing assumptions of the model, in accordance to the literature that evidence the strong relation between knowledge and behavior.

5. As the managerial attitudes of brand manufacturers for customers' participation in marketing planning activities impact the perceived value of the triple pole approach, this means that brand manufacturers see an adding value through the collaboration with the retailers, because there are strongly interested in accomplishing customer relationship goals. Based on this observation, we can safely interpret that the customers (as the "C" party/player) produce a new behavioral type that converges the interest of a brand manufacturer and motivate him for building marketing alliances in vertical marketing channels. 
According to Spais, Papakonstantinidis and Papakonstantinidis (2009), the importance of this theory is arisen from the transfer of the pure trust theory to a marketing context, which can be achieved in order to analyze marketing phenomena of bargaining especially in cooperative promotion programs characterized by conflict and mistrust. Marketing phenomena refer to understanding of the bargaining problem resolution and the types of negotiation in which the marketing channel member and the business dispute the price, which will be communicated and the exact nature of the transaction that will take place and eventually come to an agreement in terms of a promotion management strategy.

The theory considers the information accessibility and diffusion that characterize the modern marketing environment, and the complexity in the decision-making of marketing channel members values that the "third win" (the "C" factor: the customer) could unlock a series of obstacles. The individual (although his/her doubts) must believe that there is a "third" distinguishable part in the bargain. The "win-win-win papakonstantinidis' theory supports the significance of the tendency to sovereignty, the tendency of conflict, which results from the combination of: a) the case of the distinguishable entity, b) mistrust of each distinguishable entity, and c) tendency to improvement in a vertical marketing channel.

Based on the assumptions of the 'win-win-win papakonstantinidis' conceptualization, the limitation in contexts such as the cooperative promotion programs, as identified in previous study (Spais, Papakonstantinidis \& Papakonstantinidis, 2009) is that utility assessment and cost-utility analyses such as costs/quality-adjusted expected profits model from the partnership for A and B parties/players and the C party/player (for customers/consumers) are frequently presented to demonstrate the value of many utility options in the marketing literature. The "C" party/player produces a new behavioral type that converges the interests of both sides, by converting a binomial distribution (, $1-\mathrm{p}$ ) into a trinomial distribution, (p1, p2, 1-p1-p2) combined with 3 utility function "prices" (Papakonstantinidis, 2011). However, utility indicators require various methods that introduce significant methodological challenges, which directly influence the results and ensuing cooperative promotion management decisions in vertical marketing channels.

\section{LITERATURE REVIEW}

Based on the search in the Scopus Database (the largest citation database), we identify thirty-one (31) published research works the last 38 years (from 1973-2011) regarding to the research topic "cooperative advertising" (which was included in the titles of the works). The results are quiet interesting, as the following figures $(1,2,3$ and 4$)$ show:

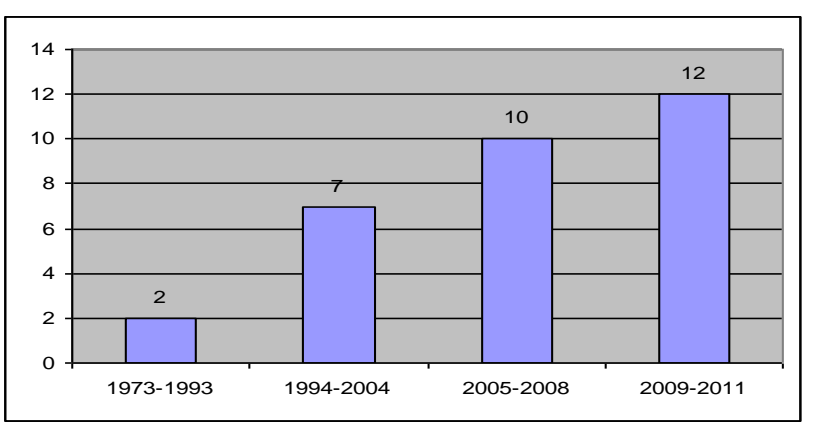

Figure 1: Published research works for "cooperative advertising" topic in a chronological order

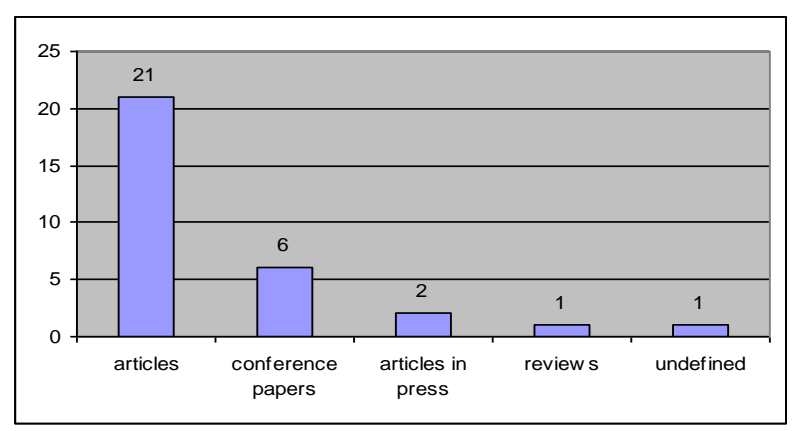

Figure 2: Published research works for "cooperative advertising" classified according to publication type 


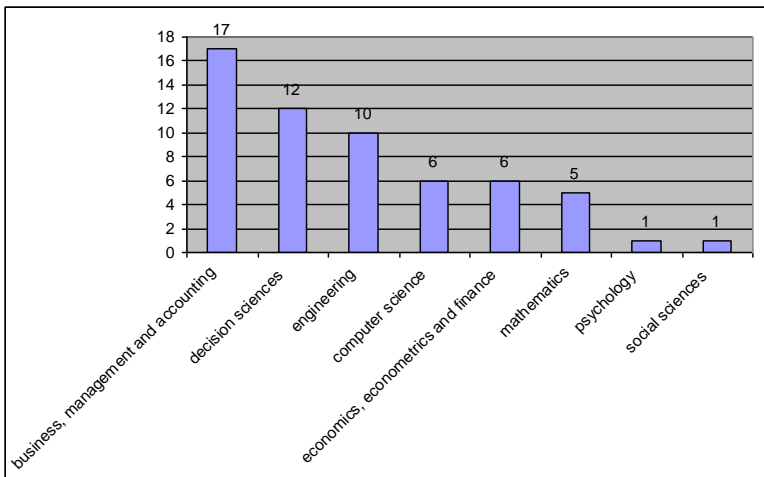

Figure 3: Published research works for "cooperative advertising" classified according to subject area

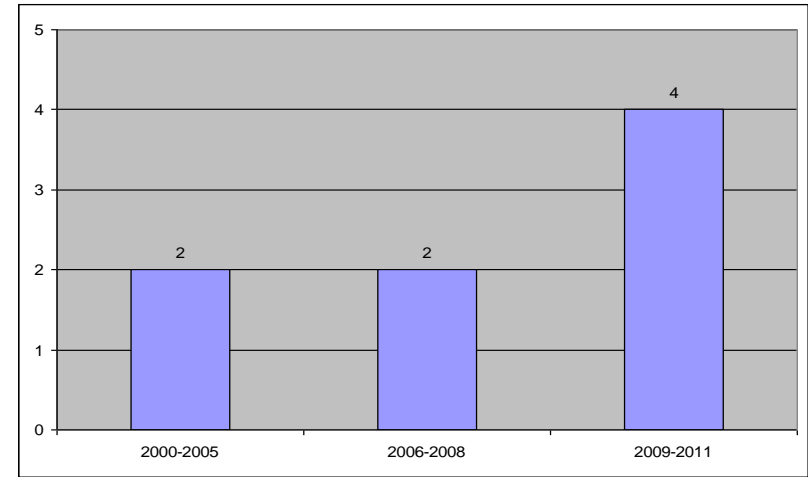

Figure 4: Published research works in "cooperative advertising" that covers bargaining issues themes presented in a chronological order

The above figures show that the research activity about the topic of cooperative advertising seems to be at a very low level at the decades ' $70 \mathrm{~s}$, ' $80 \mathrm{~s}$ and '90s. A significant increase of the research interest is presented after 2005. Is quiet remarkable that published research works in cooperative advertising are presented in publications from different subject areas.

According to AMA's definition for the term "vertical cooperative advertising", presented in the section of "Introduction", bargaining seems to be a vital component of the term, it's quiet impressing that only eight (8) published research works in "cooperative advertising" are covering bargaining issues research themes. A chronological order of these research works are presented in Figure 4. Table 2 summarizes information about the focus of these works, the publication names and their impact.

Table 2: Examining the assumptions of the two theoretical perspectives from the two theories

\begin{tabular}{|c|c|c|c|c|}
\hline Title of the paper/focus & Author(s) & $\begin{array}{l}\text { Publication } \\
\text { year }\end{array}$ & Publication name & $\begin{array}{l}\text { Impact (no. } \\
\text { citations till } \\
\text { Nov.2011) }\end{array}$ \\
\hline $\begin{array}{l}\text { Coordination via cost and revenue sharing in } \\
\text { manufacturer-retailer channels }\end{array}$ & Kunter, M. & 2012 & $\begin{array}{l}\text { European Journal of Operational } \\
\text { Research (article in press) }\end{array}$ & 0 \\
\hline $\begin{array}{l}\text { A game theoretic approach to coordinate pricing and } \\
\text { vertical co-op advertising in manufacturer-retailer supply } \\
\text { chains }\end{array}$ & $\begin{array}{l}\text { Seyedesfahani, M., } \\
\text { Biazaran, M., } \\
\text { Gharakhani, M. }\end{array}$ & 2011 & $\begin{array}{l}\text { European Journal of Operational } \\
\text { Research }\end{array}$ & 0 \\
\hline $\begin{array}{l}\text { Cooperative advertising, pricing strategy and firm } \\
\text { performance in the e-marketing age }\end{array}$ & Yan, R. & 2010 & $\begin{array}{l}\text { Journal of the Academy of Marketing } \\
\text { Science }\end{array}$ & 1 \\
\hline $\begin{array}{l}\text { Coordinating advertising and pricing in a manufacturer- } \\
\text { retailer channel }\end{array}$ & Xie, J., Wei, J.C. & 2009 & $\begin{array}{l}\text { European Journal of Operational } \\
\text { Research }\end{array}$ & 12 \\
\hline $\begin{array}{l}\text { Game analysis of cooperative advertising and ordering } \\
\text { strategies in a supply chain under demand uncertainty }\end{array}$ & Fu, Q., Zeng, S.-Q. & 2008 & $\begin{array}{l}\text { Xitong Gongcheng Lilun yu } \\
\text { Shijian/System Engineering Theory } \\
\text { and Practice }\end{array}$ & 0 \\
\hline $\begin{array}{l}\text { Coordination of cooperative advertising in a two-level } \\
\text { supply chain when manufacturer offers discount }\end{array}$ & $\begin{array}{l}\text { Yue, J., Austin, J., } \\
\text { Wang, M.-C., Huang, } \\
\text { Z. }\end{array}$ & 2006 & $\begin{array}{l}\text { European Journal of Operational } \\
\text { Research }\end{array}$ & 40 \\
\hline $\begin{array}{l}\text { Cooperative advertising, game theory and manufacturer- } \\
\text { retailer supply chains }\end{array}$ & $\begin{array}{l}\text { Li, S., Huang, Z., } \\
\text { Zhu, J., Chau, P. }\end{array}$ & 2002 & Omega & 38 \\
\hline $\begin{array}{l}\text { An analysis of manufacturer-retailer supply chain } \\
\text { coordination in cooperative advertising }\end{array}$ & $\begin{array}{l}\text { Huang, Z., Li, S., } \\
\text { Mahajan, V. }\end{array}$ & 2002 & Decision Sciences & 38 \\
\hline
\end{tabular}

Based on the analysis of 56 published research works (Spais, Papakonstantinidis and Papakonstantinidis, 2009), we can summarize the following findings: 
- It seems that cooperative bargaining solution analysis results based on mathematical models can show us how to share the profit gain between the two parties in a vertical marketing channel and determine the associated pricing and advertising policies for both parties.

The bargaining problems are the:

a) complex issue of promotion activities,

b) reputation that both parties bring to the bargaining table, and

c) perceived uncertainty in the lateral environment (competitive sector).

- $\quad$ Regarding the tendency to conflict in vertical marketing channels: it seems that communication is the main source of conflict followed by different expectations and organizational structure.

- $\quad$ Regarding the tendency to sovereignty in vertical marketing channels: there is a growing dominance of large retailers, which alter the traditional channel incentives.

- Regarding the tendency to improvement for each member of the vertical marketing channel: it seems that bargaining without side payments is not effective as cooperation at reducing beggar-thyneighbor effects, it is a welfare-improving alternative to non-cooperation and is likely more practical in many situations.

- There is mistrust between the members of the vertical marketing channels.

Modern empirical evidence focus on the Customer as the third "player"/"pole" of the bargaining solution in cooperative sales promotion management process between the business and the marketing channel member (e.g. Gabrielsena and Roth, 2009; Bontems, Dhar and Chavas, 2007).

Customer as the third "party"/“player"/"pole" of the bargaining solution in cooperative sales promotion management process between the business and the marketing channel member

According to Misra and Mohanty (2008), bargaining can be seen as the process of distributing the gains obtained from trade among the participants of the trade. In the present context, the gains from trade (between the business or the manufacturer and the marketing channel member) are the total marketing channel profits. Since the wholesale price determines the proportion in which the gains from the trade (total marketing channel profit) are split between the marketing channel members, this wholesale price turns into the decision variable that is bargained over by marketing channel members. An alternative approach to measure bargaining power based on a Nash Bargaining Model between manufacturers and retailers has been recently proposed in the literature (Draganska, Klapper and Villas-Boas, 2010; Misra and Mohanty, 2008; Iyer and Villas-Boas, 2003).

There are two solution concepts for the above-mentioned bargaining problem - the co- operative approach and the non-cooperative approach (Muthoo, 1999). The asymmetric Nash bargaining solution is the cooperative approach to bargaining problems in which the asymmetry in bargaining power between the parties is taken into consideration. Encouragingly, modern empirical evidence show the raising importance of the customer to be considered as the "third party" in delegated bargaining in vertical marketing channels (between the manufacturer and the marketing channel member), (e.g. Gabrielsena \& Roth, 2009; Bontems, Dhar \& Chavas, 2007).

Optimal allocation of promotion budgets, the sales response as a budgeting method and break even sales analysis as parameters influencing bargaining solution analyses of cooperative sales promotion campaigns

The optimal allocation of the promotion budgets is an issue of practical importance (Albadvi \& Koosha, 2011; Sriram \& Kalwani, 2007). According to Gómez, and Rao (2009) and Gómez, Rao and McLaughlin (2007) the theme categories in promotion management can be classified as follows: i. the explanation of the growth; ii. the allocation of promotion budgets; iii. the extent of pass-through; iv. the balance of power between the business and the marketing channel members.

Regarding to the extent of marketing channel's member pass-through it seems that it ranges widely depending on the product category and retail price zone (e.g. Besanko, Dubé, and Gupta 2005; Tyagi, 1999). According to Cannondale Associates (2003), only 13\% of manufacturers reported receiving a good value for their promotion expenditures and, furthermore, claimed that only about half of trade funds were actually passed on to consumers. Kumar, Rajiv, and Jeuland (2001) reported higher retail margins from promotion budgets depend on the product market characteristics, such as the retailer's clientele and the heterogeneity in consumer search costs, and on frequency and budget of manufacturer deals. For example, Gómez, and Rao (2009), Drèze, and Bell (2003) report 
that marketing channel members prefer discount-based promotions flexibility and manufacturers prefer performance-based promotions. Regarding to the research thrust related to the inefficient resource allocation due to the relative power between the business and the marketing channel member as discussed in research works (e.g. Stet, 2008; Paik \& Bagchi, 2007; Scheffman, 2002; Sullivan, 2002), correlated to the distortions of demand because of the promotion campaigns.

According to Sriram and Kalwani (2007) promotions besides their strong positive effect on a brand's performance, they may also have some detrimental effects that need to be accounted for while allocating the marketing budget. Based on this observation, Naik, Raman and Winer (2005) consider interaction effects between advertising and sales promotions in addition to modeling their main effects. Regarding to the role of the budgeting method to the bargaining solution analysis for optimal budgeting in a cooperative sales promotion campaign, Dant's and Berger's study (1996) models the cooperative determination of franchisor's and franchisee's advertising contributions under conditions of differing perceptions of the sales response functions to advertising. The authors report such decisions are frequent source of conflict and the disagreements persist because of the win-win potential of vertical cooperative advertising is not well appreciated. Ending, regarding to importance of break-even sales analysis in bargaining solution analyses of cooperative sales promotion campaigns, it seems that indeed it plays a very crucial role (e.g. Roma \& Perrone, 2010; Misra, 2008; Yue et al., 2006; Dant \& Berger, 1996; Ailawadi, 2001; Morton \& Zettelmeyer, 2000).

\section{Trade promotion goals influencing bargaining solution analyses of cooperative sales promotion campaigns}

The issue of trade promotion goals seems to be underlined in terms of bargaining process in a cooperative sales promotion campaign adopting win-win trade promotion approach by Drèze and Bell (2003). According to Sigué (2008), the long-term effects of promotions on sales are increasingly linked to the supposed shift of economic power within channels from manufacturers to retailers. However, formal knowledge about how they influence channel decisions under different promotional arrangements and the distribution of channel profits remains very sparse. Sigué's findings indicate that retailers always invest in retailer promotions, while manufacturers may find it optimal not invest in consumer promotions. Economic power shifts from manufacturers to retailers when consumer promotions significantly expand the baseline demand in the long-term. Otherwise, manufacturers remain more powerful. Trade promotions or other profit-transfer mechanisms may be indispensable in easing conflicts over who should undertake promotions, especially when these promotions substantially increase future sales. Based on the literature review findings, we extend the three adjusted utility functions (1), (2) and (3) incorporating the parameters of sales response budgeting method, the break-even sales analysis and the independent variable of the trade promotion goals that lead us to the utility functions (4), (5) and (6). The extended adjusted utility functions and the constraints (8), (9) and (10) derived from the win-win-win papakonstantinidis model are presented in the next section.

\section{METHODOLOGY}

Critical cases for the study of promotion and promotion management phenomena seems to gain more and more the research interest by the members of the academic community for he marketing discipline as they realize the value of becoming critically aware of the practical wisdom of promotion events and relative managerial practices, in accordance to the critical case study conceptualization by Flyvbjerg (1991).

\section{Research method, unit of analysis and selection of critical cases}

The investigation of an integrated bargaining solution analysis for vertical cooperative sales promotion campaigns based on the win-win-win papakonstantinidis model is a non-researched area. In order to determine winwin-win papakonstantinidis theoretical perspectives of the bargaining solution analysis for vertical cooperative sales promotion campaigns (regarding to promotion costs allocation), it is incumbent upon marketing scholars and researchers to take the above perspective, which allows these issues to be arisen. The use of the case study is considered to be of high value in our analysis because in the empirical studies none of promotion phenomena are very well understood (Cutler, 2004). The research method of case study is introduced in order to reveal very new constructs and to attempt to establish an initial understanding of the constructs and their relationship with other 
constructs (Yin, 1994). Human activity is the basic unit of the analysis of the critical case. Incorporates notions of understanding such as mediation, motivation and culture. We believe that the four (4) cases of cooperative marketing programs may give valuable information. Information that deepen our understanding of the characteristics of vertical cooperative sales promotion campaigns and, thus, the phenomenon studied can become more visible, as Stake (1994) argued. The different aspects of a context, from which a particular problem situation originates, can become increasingly visible and more accessible for a promotion management researcher (e.g. Spais, 2010; 2011). Based on Uden, Valders and Pastor's work (2008), we adopt the following linear process in order to gather the data in the critical cases: $i$ ) clarification of the purpose(s) of the activity system; ii) analysis of the activity system and production of the activity system; and iii) analysis of the activity structure.

\section{Evaluation and analysis of the data}

The data of activity structure analyses resulted from the performance of four (4) critical case studies analyses from September 1 to September 22, 2011 [in accordance with the methodological guidelines for qualitative content analysis in case study research of Kohlbacher (2006)] utilizing the conceptual categories of -activity system for the understanding the nature and the characteristics of cooperative marketing and advertising campaigns. The findings of the cases' analysis are presented in the following section.

\section{FINDINGS}

Table 3 presents the summarized details in accordance to the unit of analysis described above:

Table 3: Summary of data analysis of the four (4) cases of cooperative marketing programs based on the activity system structure in order to deepen the understanding of the characteristics of vertical cooperative sales promotion campaigns Case: Destination Management Organizations (DMOs) and Small and Medium-Sized Tourism Enterprises (SMTEs) Cooperative CRM in Alpine Tourist Destinations

Title of the cooperative marketing program: "CRM in Alpine Tourist Destinations"

Background: The success of tourist destinations depends largely on effective relationships between destination management organizations (DMO) and enterprises in alpine regions these are mainly small and family managed service providers. The use of internet technologies offers vast potential for developing a process of cooperative promotion of a region in order to attract travellers (Palmer \& McCole, 2000, Williams \& Palmer, 1999). Whilst online booking and reservation services can be said to have been accepted by service providers, the 'e-Business Scoreboard 2005: Tourism' indicates that technologically enhanced customer relationship management (CRM) is not 'widely diffused among the smaller firms'. However, according to an explorative study in the tourism sector in Austria and Switzerland, expenditure on electronic marketing instruments, such as email marketing, is expected to increase by up to $30 \%$ from the present state. A vast potential for improvement shows up in the performance measurement of marketing communication. In Switzerland and Austria $40 \%$ of the hotels, do not have processes for measuring the success of marketing activities. In addition to enterprise-specific marketing activities, cooperative marketing arrangements are quite common in tourist destinations and offer clear advantages for all involved participants.

\begin{tabular}{|c|c|c|c|c|}
\hline \multicolumn{5}{|c|}{$\begin{array}{l}\text { Source: Cooperative Customer Relationship Management (CRM) in Alpine Tourist Destinations } \\
\text { Fux, M., Mathieu, D. and Myrach, T. (2007). Proceedings of the } 2007 \text { ECIS. } \\
\text { Available: http://is2.lse.ac.uk/asp/aspecis/20070057.pdf }\end{array}$} \\
\hline subject & tool & object & goal & result \\
\hline $\mathrm{DMO}$ & $\begin{array}{l}\text { Internet technology is a } \\
\text { major enabler for } \\
\text { collaboration in customer- } \\
\text { oriented processes; in this } \\
\text { case a corporate CRM } \\
\text { infrastructure for tourist } \\
\text { destinations }\end{array}$ & $\begin{array}{l}\text { Internet technology is a } \\
\text { major enabler for } \\
\text { collaboration in customer- } \\
\text { oriented processes; in this } \\
\text { case a corporate CRM } \\
\text { infrastructure for tourist } \\
\text { destinations. Besides this } \\
\text { crucial technological } \\
\text { driver, the need for an } \\
\text { increased customer- } \\
\text { orientation in marketing } \\
\text { activities through the }\end{array}$ & $\begin{array}{l}\text { In the current model of } \\
\text { collaboration in marketing } \\
\text { campaigns, the } \\
\text { service providers and the } \\
\text { destination management } \\
\text { organization determine a } \\
\text { common understanding } \\
\text { about the strategic } \\
\text { objectives and their roles } \\
\text { in the destination } \\
\text { network. From a process } \\
\text { perspective, it }\end{array}$ & $\begin{array}{l}\text { The campaign } \\
\text { management system } \\
\text { supports the planning of } \\
\text { marketing activities by } \\
\text { defining } \\
\text { parameters such as target } \\
\text { group, content, or } \\
\text { schedules for the } \\
\text { individual campaigns, and } \\
\text { the service } \\
\text { providers which could be } \\
\text { invited to participate. The }\end{array}$ \\
\hline
\end{tabular}




\begin{tabular}{|c|c|c|c|c|}
\hline & & $\begin{array}{l}\text { utilization of knowledge } \\
\text { about customers forces a } \\
\text { change in marketing } \\
\text { communications. This } \\
\text { adaptation is required in a } \\
\text { context of increased } \\
\text { competition among tourist } \\
\text { destinations and } \\
\text { augmented problems of } \\
\text { small- and medium } \\
\text { tourism enterprises } \\
\text { (SMTE) in handling } \\
\text { customer-oriented } \\
\text { processes in an electronic } \\
\text { environment. By } \\
\text { implementing a } \\
\text { cooperative CRM } \\
\text { initiative, a lacking } \\
\text { motivation to cooperate of } \\
\text { SMTE and technical } \\
\text { interoperability of } \\
\text { existing information } \\
\text { systems, have to be } \\
\text { considered as } \\
\text { impedimental factors. }\end{array}$ & $\begin{array}{l}\text { is defined how the } \\
\text { involved actors are } \\
\text { planning, executing and } \\
\text { analyzing marketing } \\
\text { campaigns. These } \\
\text { processes are supported } \\
\text { by an inter-organizational } \\
\text { CRM infrastructure, } \\
\text { consisting of analytical, } \\
\text { operational and } \\
\text { collaborative system } \\
\text { components. }\end{array}$ & $\begin{array}{l}\text { system supports } \\
\text { development of a } \\
\text { campaign using existing } \\
\text { design templates, with } \\
\text { which new campaigns can } \\
\text { be more efficiently } \\
\text { prepared. The campaign } \\
\text { content is compiled in the } \\
\text { form of blocks in a } \\
\text { separate design template } \\
\text { and linked with suitable } \\
\text { keywords. The system } \\
\text { compares these keywords } \\
\text { with the available } \\
\text { customer information and } \\
\text { generates personalized } \\
\text { content for each customer } \\
\text { in the target group. In } \\
\text { addition to obtaining } \\
\text { further } \\
\text { information on customer } \\
\text { interests, the relevance of } \\
\text { individual articles or } \\
\text { offers can be determined } \\
\text { using click-tracking. }\end{array}$ \\
\hline
\end{tabular}

Case: IBM

Title of the cooperative marketing program: "Smarter Planet"

Background: International Business Machiness, abbreviated IBM and nicknamed "Big Blue", is a multinational computer technology and IT consulting corporation headquartered in Armonk, New York (USA). The company is one of the few information technology companies with a continuous history dating back to the 19th century. IBM manufactures and sells computer hardware and software (with a focus on the latter), and offers infrastructure services, hosting services, and consulting services in areas ranging from mainframe computers to nanotechnology. In a joint engagement, IBM and Nokia Siemens Networks designed and built a SOA-based service creation and delivery platform that enables Globe Telecom (from Philippines) to rapidly and cost-effectively create service offerings from reusable service components. Globe Telecom, the number two mobile communication services provider in the Philippines, with 27 million customers, recognized that the most effective way to attract and retain the value-conscious Philippine mobile customer was to spur action through time-limited marketing promotions. In such an environment, success comes to the fast, nimble and intelligent - defined by the ability to target market opportunities with tactical campaigns, monitor their effectiveness and fine tune them in short order. That is exactly how Globe Telecom-the number two provider in the Philippines, with 27 million customers-is approaching the competitive challenge. Globe specifically recognized that the most effective way to attract and retain the value-conscious Philippine mobile customer was to spur action through time-limited marketing promotions - for example, reload HSDPA service with PHP30 and get 24 hours unlimited SMS product. Call it opportunistic marketing in the extreme. While Globe's marketing staff had no shortage of creative promotional ideas - or the energy to carry them out — the company's heavy reliance on its traditional vendors (particularly IN) to develop new services put a major drag on its agility. Under a typical scenario, it took roughly 10 months and most often several hundreds of thousands of dollars to develop and bring a new service to market. Moreover, the fact that each of Globe's lines of business operated its own service creation silo made the creation of bundled, composite service promotions equally complex due to integration requirements.

Source: Globe Telecom: Gaining marketing agility with smart promotions

Available: http://www-01.ibm.com/software/success/cssdb.nsf/CS/JSTS-7Z7K7B?OpenDocument\&Site=default\&cty=en_us

\begin{tabular}{|c|l|l|l|l|}
\hline subject & \multicolumn{1}{|c|}{ tool } & \multicolumn{1}{c|}{ gobject } & \multicolumn{1}{c|}{ result } \\
\hline IBM & $\begin{array}{l}\text { IBM and Nokia Siemens Networks } \\
\text { designed and built a SOA-based service } \\
\text { creation and delivery platform that enables }\end{array}$ & $\begin{array}{l}\text { Globe Telecom } \\
\text { needed to reach } \\
\text { a new level of } \\
\text { agility in the } \\
\text { Globe Telecom (from Philippines) to } \\
\text { rapidly and cost-effectively create service } \\
\text { offerings from reusable service components. } \\
\text { creation and } \\
\text { management of } \\
\text { promotional }\end{array}$ & $\begin{array}{l}\text { Expected } \\
\text { payback } \\
\text { period; } 600 \\
\text { percent } \\
\text { increase in } \\
\text { promotion }\end{array}$ & $\begin{array}{l}\text { Globe is using the Toolbox to } \\
\text { seize customer opportunities is } \\
\text { through the intelligent sensing } \\
\text { needs, and the ability to respond } \\
\text { to it in a targeted, timely and } \\
\text { compelling way. The key to } \\
\text { opportunistic marketing is }\end{array}$ \\
\hline
\end{tabular}




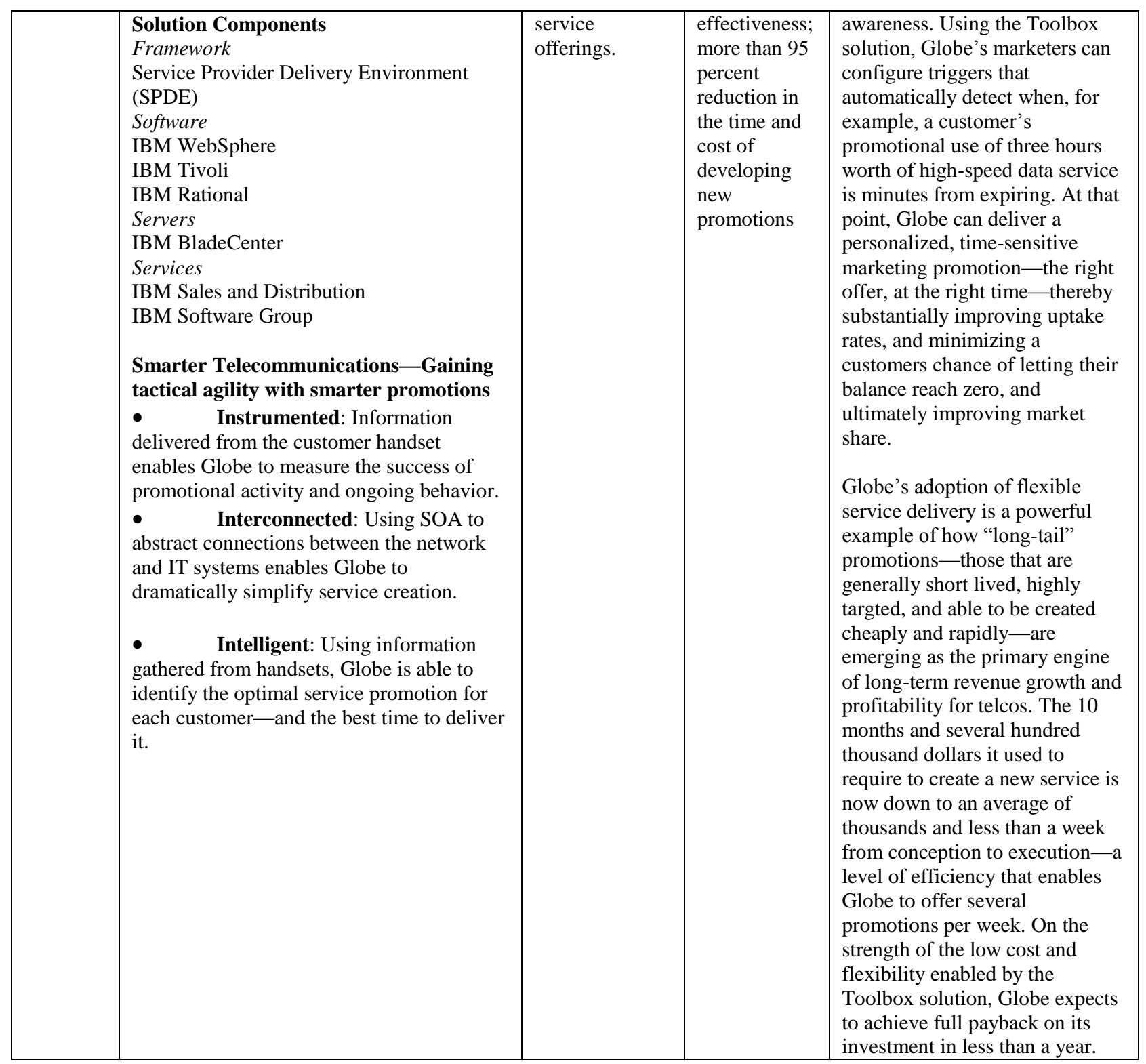

Case: New York State Energy Research and Development Authority (NYSERDA)

Title of the cooperative marketing program: "Energy \$mart program"

Background: New York State Energy Research and Development Authority (NYSERDA), a public benefit corporation funded by state utility- ratepayer System Benefits Charges, operates the New York Energy \$mart initiative. This initiative includes an Home Performance with Energy Star (HPwES) program that encourages comprehensive energy upgrades in existing one- to fourunit residential homes through an independent network of home-improvement contractors accredited by the Building Performance Institute (BPI).1 To participate, a homeowner contacts a contractor from the list of approved contractors available on the Energy \$mart website, and the contractor then serves as a one-stop shop-performing a home energy assessment, installing energy improvements, and offering HPwES financing and rebate options. NYSERDA offers a range of incentives to encourage contractors to participate in the HPwES program including discounts on BPI certification, subsidies for diagnostic equipment, listing on the Energy \$mart website, access to consumer financing options and incentives, use of NYSERDA marketing materials, referrals/leads from NYSERDA's public awareness campaigns, and co-operative advertising reimbursements. Most of these incentives are performance-based, which allows NYSERDA to encourage scale, reward performance, and maximize its resources. 
Source: Driving Demand for Home Energy Improvements

Fuller, M., C. Kunkel, M. Zimring, I. Hoffman, K.L. Soroye, and C. Goldman. LBNL-3960E. September 2010.

This case study is part of a larger report available here: http://drivingdemand.lbl.gov/

\begin{tabular}{|c|c|c|c|c|}
\hline subject & tool & object & goal & result \\
\hline $\begin{array}{l}\text { New York } \\
\text { State Energy } \\
\text { Research and } \\
\text { Development } \\
\text { Authority } \\
\text { (NYSERDA }\end{array}$ & $\begin{array}{l}\text { While contractors are the key point of } \\
\text { customer contact, Energy \$mart runs an } \\
\text { extensive marketing campaign (involving } \\
\text { television, radio, newspaper, direct mail, } \\
\text { public relations, and special events) to build } \\
\text { recognition for HPwES and other NYSERDA } \\
\text { programs encouraging residential energy } \\
\text { efficiency. NYSERDA's HPwES advertising } \\
\text { is intended strictly to help catalyze the } \\
\text { development of a robust market for the } \\
\text { HPwES program, not to extend NYSERDA's } \\
\text { own brand. Contractors mention that this } \\
\text { singular focus has contributed to the success } \\
\text { of establishing the HPwES brand in New } \\
\text { York. NYSERDA couples its general HPwES } \\
\text { marketing with cooperative advertising } \\
\text { incentives that reimburse contractors for a } \\
\text { portion of their own advertising expenses. The } \\
\text { reimbursement rates and caps are a function of } \\
\text { the number of upgrades a contractor completes } \\
\text { and range from } 25 \% \text { to 50\% of a given } \\
\text { advertising expense up to a maximum of } \\
\text { \$150,000 annually per contractor. } \\
\text { people say that understanding the amount of } \\
\text { money is most effective in encouraging them } \\
\text { to invest in home energy improvements. } \\
\text { NYS-Sale Training and Messaging } \\
\text { progER operates a one-day training } \\
\text { program in sales and marketing that teaches } \\
\text { contractors skills on communicating the } \\
\text { importance of HPwES and a whole-house } \\
\text { approach to energy efficiency. This training } \\
\text { focuses on the customer experience and } \\
\text { addresses some of the key hurdles to } \\
\text { converting leads into jobs. Experienced } \\
\text { whole-home energy-efficiency contractors } \\
\text { note that programs often spend a lot of time on } \\
\text { technical training but not nearly enough on } \\
\text { showing contractors how to make a living } \\
\text { performing energy efficiency improvements. } \\
\text { HPwES programs typically add overhead } \\
\text { costs to businesses and contractors must be } \\
\text { able to educate homeowners and communicate } \\
\text { the benefits of a whole-home approach to } \\
\text { energy efficiency to beat out their competitors. } \\
\text { adigns focus on saving money. }\end{array}$ & $\begin{array}{l}\text { HPwES cooperative } \\
\text { advertising incentives } \\
\text { allow NYSERDA to } \\
\text { leverage its } \\
\text { advertising dollars } \\
\text { and control the } \\
\text { message while } \\
\text { harnessing } \\
\text { contractors to sell the } \\
\text { program. Contractors } \\
\text { benefit from the } \\
\text { financial assistance } \\
\text { and NYSERDA's } \\
\text { broader HPwES } \\
\text { branding campaign. }\end{array}$ & $\begin{array}{l}\text { Leveraging } \\
\text { contractors' } \\
\text { ability to sell } \\
\text { home energy } \\
\text { upgrades }\end{array}$ & $\begin{array}{l}\text { Since } 2001 \text {, over } \\
32,000 \text { home energy } \\
\text { upgrades worth more } \\
\text { than } \$ 247 \text { million } \\
\text { have been completed } \\
\text { through HPwES by } \\
\text { approximately } 250 \\
\text { participating } \\
\text { contractors3. These } \\
\text { improvements have } \\
\text { saved over } 22 \\
\text { million kWh and } \\
\text { over } 1 \text { million } \\
\text { MMBTU to date. All } \\
\text { of the program's } \\
\text { active contractors } \\
\text { have used } \\
\text { NYSERDA } \\
\text { incentives to earn } \\
\text { BPI certifications. } \\
\text { Since } 2003 \text {, HPwES } \\
\text { penetration of New } \\
\text { York's home } \\
\text { remodeling market } \\
\text { has climbed from } \\
\text { less than } 0.5 \% \text { to } \\
\text { approximately } 3 \% \\
\text { annually. } \\
\text { NYSERDA has paid } \\
\text { almost } \$ 3.5 \text { million } \\
\text { to contractors since } \\
\text { the cooperative } \\
\text { advertising initiative } \\
\text { began in } 2001 . \text { This } \\
\text { public spending } \\
\text { enhances } \\
\text { contractors' ability } \\
\text { to convert marketing } \\
\text { expenditures into } \\
\text { jobs and has been } \\
\text { leveraged into over } \\
\$ 10 \text { million of total } \\
\text { contractor spending } \\
\text { on outreach. Over } \\
20 \% \text { of active } \\
\text { HPwES contractors } \\
\text { used the cooperative } \\
\text { marketing in } 2010 . \\
\text { cYSERDA is } \\
\text { considering } \\
\text { developing } \\
\text { templates that weenen bilt smalless active }\end{array}$ \\
\hline
\end{tabular}




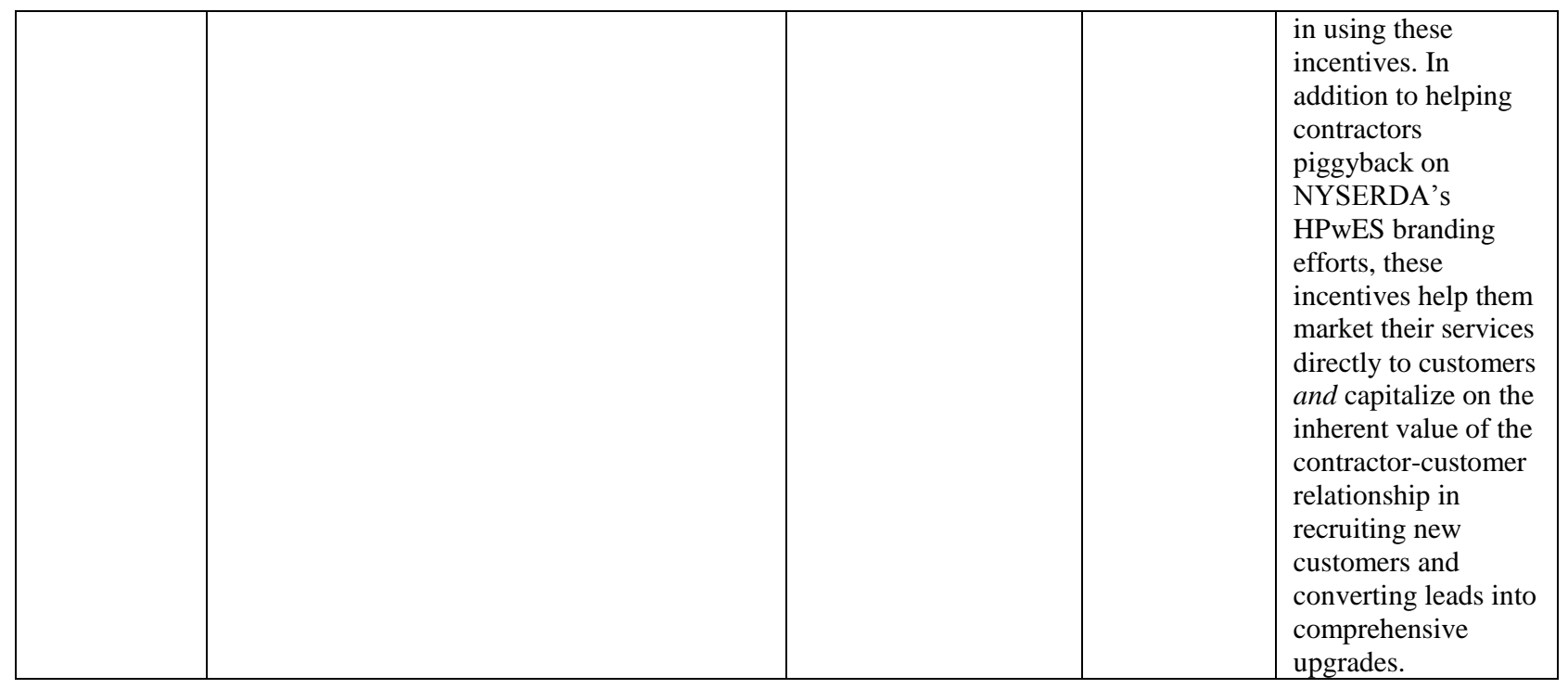

Case: Hewlett-Packard (HP)

Title of the cooperative marketing program: "HP Online-To-Store"

Background: HP is an American multinational information technology corporation headquartered in Palo Alto, California, USA that provides products, technologies, software's, solutions and services to consumers, small- and medium-sized businesses (SMBs) and large enterprises, including customers in the government, health and education sectors. Bill Hewlett and Dave Packard founded the company in a one-car garage in Palo Alto. Currently, HP is the world's leading PC manufacturer, operating in nearly every country. It specializes in developing and manufacturing computing, data storage, and networking hardware, designing software and delivering services. Major product lines include personal computing devices, enterprise, and industry standard servers, related storage devices, networking products, software and a diverse range of printers, and other imaging products. HP markets its products to households, small- to medium-sized businesses and enterprises directly as well as via online distribution, consumer-electronics and office-supply retailers, software partners and major technology vendors. HP also has strong services and consulting business around its products and partner products.

\begin{tabular}{|c|c|c|c|c|}
\hline \multicolumn{5}{|c|}{$\begin{array}{l}\text { Source: HPOnline-to-Store Case Study } \\
\text { Available: http://www.thinkwithgoogle.com/insights/library/studies/hp-online-to-store-case-study/ }\end{array}$} \\
\hline subject & tool & object & goal & result \\
\hline HP & $\begin{array}{l}\text { Co-op advertising is a key strategic marketing } \\
\text { platform, where manufacturers such as HP } \\
\text { partner with retailers to drive sales. Google } \\
\text { can help advertisers build, manage and } \\
\text { measure results of a digital co-op marketing } \\
\text { program, targeted at the vast and engaged } \\
\text { online audience. HP partnered with a national } \\
\text { retailer to launch the digital co-op program } \\
\text { (APT). The campaign was conducted for } 4 \\
\text { weeks in } 2010 \text {. } \\
\text { APT has partnered with over } 50 \text { global } 2000 \\
\text { leaders to test proposed initiatives, learn from } \\
\text { results, accurately predict the impact of } \\
\text { decisions, and maximize profits. } \\
\text { Test vs. Control Methodology } \\
1 . \text { Geographically diverse test markets spread } \\
\text { across the country were served Google search } \\
\text { ads for HP branded terms and non-branded } \\
\text { keywords. The control markets were not } \\
\text { served search advertising related to these } \\
\text { keywords. }\end{array}$ & $\begin{array}{l}\text { Google partnered } \\
\text { with Applied } \\
\text { Predictive } \\
\text { Technologies (APT) } \\
\text { to evaluate the sales } \\
\text { lift with high } \\
\text { significance. }\end{array}$ & $\begin{array}{l}\text { Quantify the } \\
\text { impact of an } \\
\text { HP } \\
\text { computing } \\
\text { digital co-op } \\
\text { search } \\
\text { marketing } \\
\text { campaign on } \\
\text { in-store sales } \\
\text { to make } \\
\text { confident } \\
\text { decisions } \\
\text { about } \\
\text { discretionary } \\
\text { media and } \\
\text { co-op budget } \\
\text { allocation. }\end{array}$ & $\begin{array}{l}530 \% \text { overall return- } \\
\text { on-ad-spend for } \\
\text { computing category } \\
\text { ( } \$ 5.30 \text { in sales for } \\
\text { every } \$ 1.00 \text { of } \\
\text { search media). } \\
\text { Search ads targeted } \\
\text { to top } 25 \% \text { of } \\
\text { markets based on } \\
\text { specific store } \\
\text { attributes produced } \\
1,090 \% \text { return-on- } \\
\text { ad-spend for } \\
\text { computing category. }\end{array}$ \\
\hline
\end{tabular}




\begin{tabular}{|l|l|l|l|}
\hline & $\begin{array}{l}\text { 2.To minimize noise, APT's software } \\
\text { compares each test store's performance } \\
\text { against a unique set of 10 control stores based } \\
\text { on historical sales patterns, population density } \\
\text { and geographic proximity. }\end{array}$ & & \\
$\begin{array}{l}\text { 3.Using APT's sophisticated analysis } \\
\text { software, sales in each test store were } \\
\text { compared to its control store group to } \\
\text { determine the impact of paid search } \\
\text { advertising on store and online sales. }\end{array}$ & & \\
\hline
\end{tabular}

Based on the above analysis, we can interpret and summarize the following findings regarding to crucial characteristics of cooperative sales promotion campaigns:

- Successful brand manufacturers see an adding value through the collaboration with the retailers, because there are strongly interested in accomplishing customer relationship goals.

- The most significant strategic factor that successful brand manufacturers consider is the increasing customers' participation rates through loyal customers, as the result of individualized marketing. Best practice can be found at cases of cooperative sales promotion campaign, where content of cooperative marketing campaigns is based on customer's socio-demographic and behavioral characteristics and his demands assessed in a continuous base.

- The main objective for successful brand manufacturers is to approach customer's needs individually and to direct campaigns at specific target groups.

- Because of an information overflow on the customer side, successful brand manufacturers see the relevance of marketing communication as a crucial success factor that requires innovative strategies towards a one-toone marketing approach.

- The successful brand manufacturers agree on how customer-oriented processes should be implemented and how responsibilities for complete, or partial, processes should be regulated.

- Intervening conditions of cooperative sales promotion campaigns may be grouped into two sections: i) technological impediments; and ii) organizational impediments.

- Three contexts may influence the decision selection for successful brand manufacturers among different cost effective promotional tools: i) environmental (e.g. market conditions); ii) organizational (e.g. size of the two parties); and iii) level of ICT inadequate knowledge and technophobia.

\section{THE PROPOSITION: THE INTEGRATED BARGAINING SOLUTION ANALYSIS}

The extended "spais-papakonstantinidis-papakonstantinidis" model is presented in this section, including: i) the adjusted utility functions of the three "players"; ii) the definition of the "sensitization" process; ii) the referee solution, the optimal solutions for the three players and the constraints derived from the win-win-win papakonstantinidis model; iii) a presentation of the potential outputs from a bargaining process regarding to the sharing of the cooperative sales promotion cost among "A", "B" and "C" parties/players for different sales promotion offerings, based on a hypothetical numerical example; and iv) the role of configuring the "sensitized game" in order to deepen the understanding of the bargaining characteristics.

We consider the business, which is the promotion planner as the A factor, with utility maximizing the profits $\hat{e}$ in a given period $t(t=0,1,2, \ldots . T)$ for the brand $p(p=1,2, \ldots P)$. We can compute the per period profit for the brand as:

$$
\begin{gathered}
\max U_{e ̂ p}^{t} t=\left(W_{p t}-c_{p}-P r_{p t}\right) * S p t \\
p=0,1,2, \ldots, P, t=0,1,2, \ldots, T
\end{gathered}
$$

where:

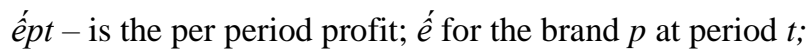

$W p t-$ is the wholesale price $W$ for the brand $p$ at period $t$; 
$c p$ - is the marginal cost for the brand $p$;

Prpt - is the promotion, respectively of brand $p$ at period $t$;

$S p t$ - is the business' existed level of sales for brand $p$ at period $t$;

$M D t$ - is the marketing decision cost at period $t$;

$S O_{p t B S}$ is the objective of minimum sales volume for brand $p$ at period $t$ based on the break-even sales;

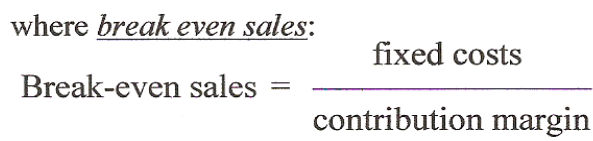

where contribution margin:

Contribution margin $=\frac{\text { brand's price }- \text { variable cost }}{\text { brand's price }}$

$A D t d s / d t-$ is the total advertising budget at period $t$ considering $d S / d t$; where $\underline{d S / d t}$ according to Vidale-Wolfe model (1957):

$\mathrm{dS} / \mathrm{dt}=\mathrm{rA}(\mathrm{t})(\mathrm{M}-\mathrm{S}) / \mathrm{M}-\lambda \mathrm{S}, \quad$ where:

$\mathrm{S}=$ sales volume at period $t$

$\mathrm{dS} / \mathrm{dt}=$ change of sales volume at period $t$

$r=$ response constant

$A(t)=$ rate of advertising expenditure

$\mathrm{M}=$ saturation level of sales

$\lambda=$ exponential sales decay constant (lost sales) when $A(t)=0$

$P R t d s / d t$ - is the total promotion budget at period $t$ considering $d S / d t$;

$\xi_{p t}$-is the mean utility to consumers/customers from the brand $p \mathrm{~s}$ at period $t$ due to

unobserved variables.

We consider the marketing channel member as the B factor, with utility maximizing the profits $\hat{e}$ for the marketing channel member from the partnership with the business in a given period $t(t=0,1,2, \ldots . T)$ for the marketing channel member (mediating, facilitating and sales) services to the business $\operatorname{sop}(\mathrm{sop}=1,2, \ldots S)$. We can compute the per period profit for the marketing channel member services as:

$$
\begin{aligned}
\max U \hat{e ̂ s t}^{\prime}= & \left(c_{p}-\operatorname{Pr}_{p t t}\right) * \operatorname{mspt}\left(M D_{t}, S O_{p t B S}, T P G_{p t}, A D_{t d s} / d t, P R_{t d s} / d t, \xi_{s t}\right)-A D_{s t} \\
& \operatorname{Sop}=0,1,2, \ldots, S_{o p}, s=0,1,2, \ldots, S, t=0,1,2, \ldots, T(5)
\end{aligned}
$$

where:

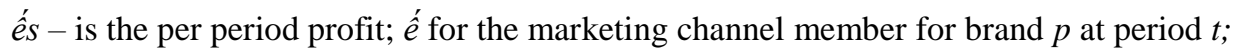

$c p$ - the marginal cost for the brand $p$ for the marketing channel member;

Prpt - is the promotion, respectively of brand $p$ at period $t$;

$m s p t$ - is marketing channel member's existed level of sales for brand $p$ at period $t$;

$M D t-$ is the marketing decision cost for the marketing channel member at period $t$;

$S O_{p t B S}$ is the objective of minimum sales volume for brand $p$ at period $t$ based on the break-even sales;

where break even sales:

$$
\text { Break-even sales }=\frac{\text { fixed costs }}{\text { contribution margin }}
$$

where contribution margin:

Contribution margin $=$

brand's price - variable cost

brand's price 


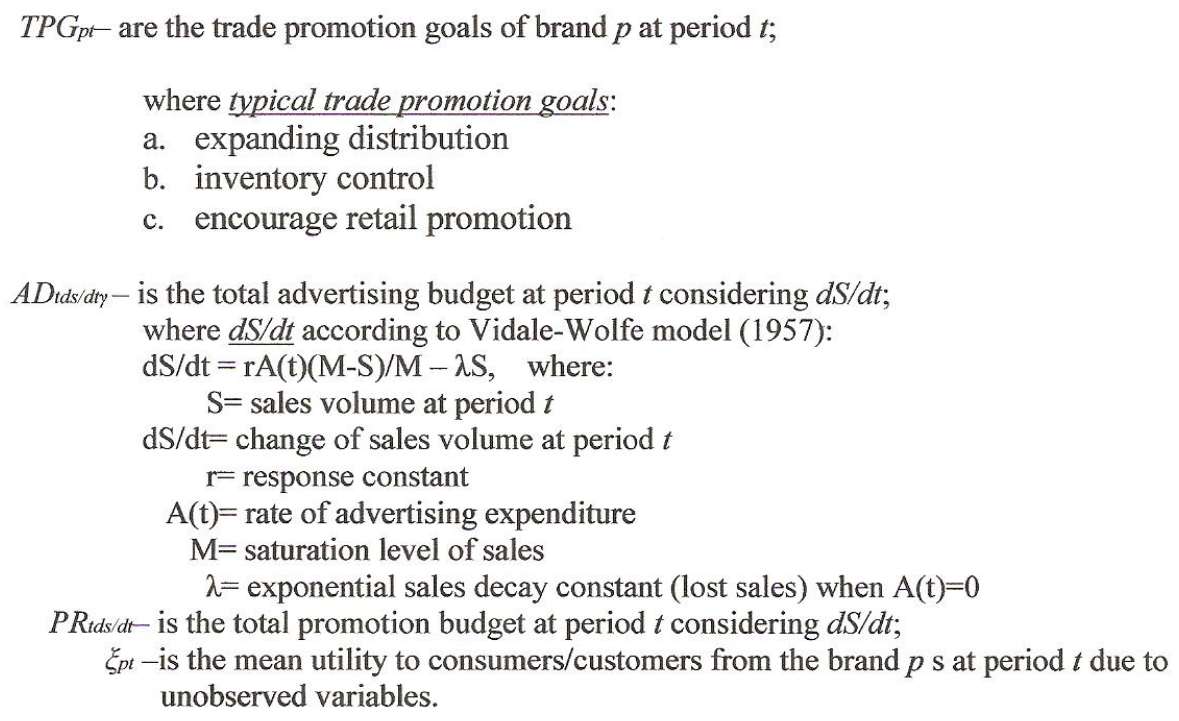

We consider a market with utility-maximizing customers/consumers $c$ who while visiting the point of sale in a given period $t(t=0,1,2, \ldots . T)$ may choose to purchase the brand $p(p=1,2, \ldots P)$ within a category or may purchase a competitive brand (equivalent to not purchasing in the category, denoted by $p=0$ ). The presence of the outside alternative in our model allows for the potential sales increase. We represent the utility that customer/consumer $c$ derives from brand $p$, at period $t$.

$$
\begin{aligned}
\max U_{c t} & =\beta o_{c s t}+\alpha_{c} P_{s t}+\beta X_{s t}+\gamma_{c} P_{s t}+\xi_{s t}+\varepsilon_{c s t} \\
p & =0,1,2, \ldots, P, t=0,1,2, \ldots, T(6)
\end{aligned}
$$

where:

$\beta 0 c s t-$ is the utility that customer/consumer $c$ derives from brand $p$ at period $t$;

$P s t-$ is the regular price, respectively for brand $p$ at period $t$;

$X s t$ - is a vector of factors that influence the customer's/consumer's utility including

demand drivers such as seasonal factors at period $t$;

Prst - is the promotion, respectively of brand $p$ at period $t$;

$\xi p t-$ is the mean utility to customers/consumers from brand $p$ at period $t$ due to unobserved variables;

$\varepsilon c p t$ - is the loyalty of customers/consumers $c$ to the brand $p$ at period $t$.

In Equation (3), we assume that the consumers/customers in each period will choose to purchase one of the brands at the point of sale $p$ or settle for the outside good depending on the utility that they expect to derive from each choice alternative. So, their purchase choice is based on a consideration of the: a) characteristics of competitive brands, b) regular prices of competitive brands, c) promotional deals, d) seasonality, and e) marketing channel member's corporate name.

In order to deepen our understanding for the following constraints, we have to consider the relation between knowledge and behavior (which is strongly evidenced in the literature) and consists one of the prevailing assumptions of the "win-win-win papakonstantinidis model" (the "interaction on bargain-behavior"). The different examples of knowledge types synthesis and the resulted 1-1 behavior leads us to understand the bargain-behavior assumption, based on information given. From the other hand, bargainers' information may be the dominant result of this cross-related knowledge types (Papakonstantinidis, 2011).

Despite Nash "complete bargainers information" Harsanyi distinguished between complete and incomplete information, that each player has from the others bargaining behavior. Thus, the hypothesis of bargain-behavior interaction is very important in building the suggested "C Factor" following the Harsanyi's Bayesian Theorem 
original game can be replaced by a game "where nature first conducts a lottery in accordance with the basic probability distribution" (Harsanyi, 1967). This extension is mainly based on the "Harsanyi's transformation", with a difference: original bargain between two can be replaced by a game, where the C Factor first conducts a lottery in accordance with the basic probability distribution. In addition, the " $\mathrm{C}$ " factor should be seen as the result of a "new" suggested bargaining behavior, coming from sensitization process (Papakonstantinidis, 2011; 2007; 2004a; 2004b; $2003 ; 2002)$. In such a context, the $C$ party/player is given in terms of a continuous sensitization process, tending to sensitization itself, inside the customers. In accordance to Papakonstantinidis proposal (2011), the heart of the analysis for a bargaining solution in a cooperative promotion campaign must be the configuration of how the "sensitized game" $\left(\mathrm{G}^{* *}\right)$ is formed and developed. Such an analysis (according to Papakonstantinidis, 2011) based on Harsanyi's definition of game [who considered the: i) set of players; ii) set of actions for each player; iii) types of the players decided by the function; iv) available actions for each player; and v) payoff function of each player] must also consider a sensitization coefficient of $\mathrm{Ti}$ (see the following definition of Harsanyi).

The game definition by Harsanyi’s (1967):

The game is defined as: $G=\left\langle N, \Omega,\left\langle A_{i}, u_{i}, T_{i}, \tau_{i}, p_{i}, C_{i}\right\rangle_{i \in N}\right\rangle$, where

1. $\quad N$ is the set of players.

2. $\Omega$ is the set of the states of the nature. For instance, in a card game, it can be any order of the cards.

3. $A_{i}$ is the set of actions for player i. Let $A=A_{1} \times A_{2} \times \ldots A_{N}$.

4. $T_{i}$ is the types of player $\mathrm{i}$, decided by the function $\tau_{i}: \Omega \rightarrow T_{i}$. So for each state of the nature, the game will have different types of players. The outcome of the players is what determines its type. Players with the same outcome belong to the same type.

5. $\quad C_{i} \subseteq A_{i} \times T_{i}$ defines the available actions for player i of some type in $T_{i}$.

6. $u_{i}: \Omega \times A \rightarrow R_{\text {is the payoff function for player i. More formally, let }}$ $L=\left\{\left(\omega, a_{1}, \ldots, a_{N}\right) \mid \omega \in \Omega, \forall i,\left(a_{i}, \tau_{i}(\omega)\right) \in C_{i}\right\}$, and $u_{i}: L \rightarrow R$.

7. $p_{i}$ is the probability distribution over $\Omega$ for each player i, that is to say, each player has different views of the probability distribution over the states of the nature. In the game, they never know the exact state of the nature.

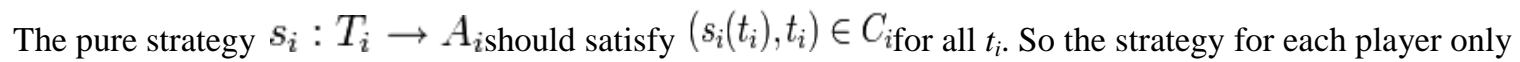
depends on his type, since he may not have any knowledge about other players' types. And the expected payoff to player $i$ for such strategy profile is: $u_{i}(S)=E_{\omega \sim p_{i}}\left[u_{i}\left(\omega, s_{1}\left(\tau_{1}(\omega)\right), \ldots, s_{N}\left(\tau_{N}(\omega)\right)\right)\right]$.

Let $S_{i}$ be the set of pure strategies, $S_{i}=\left\{s_{i}: T_{i} \rightarrow A_{i} \mid\left(s_{i}\left(t_{i}\right), t_{i}\right) \in C_{i}, \forall t_{i}\right\}$.

Next, we define the "C party/player" in terms of a continuous sensitization process, with demographic and/or pshychographic characteristics, in accordance to Siguaw and Enz (1999). These may be seen as the output of the continuous sensitization process and perfect information (the sensitization), an assumption that also considered strongly by Kunter's model (2012) and it is common by many other models (Kunter, 2012). Based on the win-winwin papakonstantinidis model can be presented: $\lim \operatorname{Pi}(\mathrm{S}) \mathrm{Qi}(\mathrm{S}) \operatorname{Ri}(\mathrm{S})=\max$ Pi Qi Ri $\quad(i \rightarrow \infty)$ where:

$\mathrm{Pi}(\mathrm{S})$ - strategy for "A player" under the probability distribution Pi

$\mathrm{Qi}(\mathrm{S})$ - strategy for "B player" under the probability distribution Qi

$\mathrm{Ri}(\mathrm{S})$-.strategy for "C player" under the probability distribution $\mathrm{Ri}$

Instead of the ad hoc solutions discussed so far, one may consider allocation mechanisms derived from the theory of cooperation as developed in game theory. Our case is equivalent to a cooperative three-players-game. The theory of cooperative games is concerned with finding a referee solution that will be accepted by all three cooperating players: 


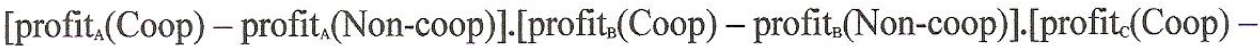

$$
\begin{aligned}
& \operatorname{profit}_{c}(\text { Non-coop)] } \Rightarrow \max !(7)
\end{aligned}
$$

The constraints presented below (8), (9) and (10):

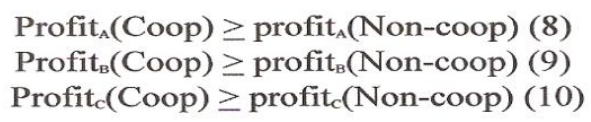

Profiti(Coop): Profit of the i-th player from the optimal solution of cooperation, Profiti(Non-coop): Profit of the i-th player from the optimal solution of non-cooperation (threat point).

Based on the above, the three "players" should only share the additional profit that results from the cooperation while receiving in advance that part of the profit that they could have achieved anyway in the case of non-cooperative behavior. The rationale behind this is that the profit can't be shared in total because the players have different threat points, i.e. profits in the case of non-cooperation. It is thereby plausible to share only the additional profit resulting from the cooperation. Constraints (8), (9) and (10) ensure that the players only accept solutions that are better than the one they could achieve in the case of non-cooperation. For our case, marketing managers have to search for a solution that maximizes the additional joint profit from cooperation (i.e. by operating a cooperative sales promotion campaign) over the respective profits in the case of non-cooperation (i.e. by operating separate sales promotion campaigns). Table 4 shows the presentation of the potential outputs from a bargaining process regarding to the sharing of the cooperative sales promotion cost among " $\mathrm{A}$ ", " $\mathrm{B}$ " and " $\mathrm{C}$ " parties/players for different sales promotion offerings based on a hypothetical numerical example:

Table 4: A presentation of the potential outputs from a bargaining process regarding to the sharing of the cooperative sales promotion cost among " $A$ ", "B" and "C" - "the sharing problem" for 5 sales promotion offerings in accordance to the assumptions of the win-win-win papakonstantinidis model based on a hypothetical numerical example

\begin{tabular}{|c|c|c|c|c|c|c|c|c|}
\hline $\begin{array}{c}\text { Sales } \\
\text { promotion } \\
\text { offerings }\end{array}$ & $\begin{array}{c}\text { Share } \\
\text { for A } \\
(\%)\end{array}$ & $\begin{array}{c}\text { Share } \\
\text { for B } \\
(\%)\end{array}$ & $\begin{array}{c}\text { Utility for } \\
\text { "A" }\end{array}$ & $\begin{array}{c}\text { Utility for } \\
\text { "B" }\end{array}$ & $\begin{array}{l}\text { Utility for } \\
\text { "A" and "B" } \\
\text { ("A"x"B") }\end{array}$ & $\begin{array}{c}\text { Share } \\
\text { for C } \\
(\%)\end{array}$ & $\begin{array}{l}\text { Utility } \\
\text { for "C" }\end{array}$ & $\begin{array}{c}\text { Utility for } \\
\text { "A", "B" and "C" } \\
(\text { ("A" x "B" x "C") }\end{array}$ \\
\hline A. & 90 & 4 & 1 & 71 & 71 & 6 & 1 & 71 \\
\hline B. & 80 & 13 & 2 & 70 & 140 & 7 & 2 & 280 \\
\hline C. & 70 & 22 & 5 & 68 & 340 & 8 & 3 & 1020 \\
\hline D. & 60 & 31 & 10 & 64 & 640 & 9 & 4 & 2560 \\
\hline E. & 50 & 40 & 16 & 60 & 960 & 10 & 5 & 4800 (MAX) \\
\hline F. & 41 & 50 & 23 & 52 & 1196 & 9 & 4 & 4784 \\
\hline
\end{tabular}

Note:

- The less shares for "A" and "B" parties/players the more share for "C" party/player.

- Utility is a personal matter: Utility units are not compared to each other. They express the fear of breaking down the agreement. If "A" party/player needs more the "agreement" than the payoff, then he should be ready to accept any form of agreement.

Considering the definition of cooperative advertising (see in Introduction), we can state that cooperative sales promotion is an arrangement where "A" party/player (e.g. a manufacturer) pays for some cost the sales promotion undertaken by a retailer for manufacturer's brands. The above hypothetical numerical example includes cost share for "A" party/player from $41-90 \%$ and for "B" party/player from $52-71 \%$. The critical role of the "C" party/player (the customer), as the "third win" in the suggested bargaining solution analysis regarding to the "sharing problem" is the share cost that the customer is willing to undertake for the promotion offering in order to get the units of utility that needs/desires. This means that the customers will try to maximize their utility by acquiring the specific promotion offering for a cost share that are willing to undertake. Therefore, the cost shares of " $\mathrm{A}$ " and "B" that are willing to undertake directly affect the share cost and the units of utility for " $\mathrm{C}$ " party/player. 


\section{DISCUSSION}

In this paper, which is conceptual in nature with strong practical implications, author's intention was to examine the possibility to investigate win-win-win papakonstantinidis model in order to develop an integrated bargaining solution analysis for vertical cooperative sales promotion campaigns. Based on previous theoretical extensions (Spais and Papakonstantinidis, 2011; Spais, Papakonstantinidis and Papakonstantinidis, 2009), this study presented an integrated bargaining solution analysis for cases of optimal allocation of a promotion budget in a cooperative sales promotion campaign in vertical marketing channels. This integrated bargaining solution analysis included: a) three (3) adjusted utility functions, considering the parameters of sales response budgeting method, the break-even sales analysis and the marketing channel member's trade promotion goals; $b$ ) the referee solution, the optimal solution for the "three players" and the constraints; c) the definition of the third win in terms of a continuous sensitization process and perfect information; and d) the presentation of the potential outputs from a bargaining process regarding to the sharing of the cooperative sales promotion cost among " $\mathrm{A}$ ", " $\mathrm{B}$ " and " $\mathrm{C}$ " parties/players for different sales promotion offerings. The basic initial assumption of this study is that different problems met in cooperative promotion planning requires adjusted bargaining solution analyses based on the winwin-win approach (including the "third win" for customers) and should not based on the traditional win-win. Encouragingly, the review of the modern literature and the critical case study confirmed the need for a win-win-win approach in cooperative sales promotion planning in vertical marketing channels. No study, until now, has offered such an innovative and integrated bargaining solution analysis conceptualization for promotion management decisions in vertical marketing channels.

The literature showed that cooperative advertising has been used by many industries for decades and continues to play a key promotional role for many manufacturers, retailers and retail customers. This is proven by significant increase of dollars spent on cooperative advertising. This increase in spending volume and the overall increase in the significance of cooperative advertising seems to motivate scholars, researchers, authors and thinkers, globally to explore more the role and use of cooperative advertising in practice, the last years. Although literature clearly shows the raising issue of reinforcing customers' participation in marketing management activities of customer-centric organizations (such as: idea generation, idea screening, concept development and testing, process design, test marketing, building promotion campaigns etc.), (e.g. Awa, 2010; Hu, Jianyou \& Na, 2010; Fang, 2008; Payne, Storbacka \& Frow, 2008; Chen \& Lu, 2007; Etgar, 2007; Lusch, Vargo \& O’Brien, 2007; Galbraith, 2005; Hip \& Grupp, 2005; Piller, 2005; Alam, 2002; Wind \& Rangaswamy, 2001; Sheth, Sisodia \& Sharma, 2000; Johne \& Storey, 1998; Sundbo, 1997; Youngdahl \& Kellogg, 1997; Wilkstrom, 1995; Dabholkar, 1990; Bowen, 1986; Lovelock \& Young, 1979) unfortunately there is no theoretical framework including the customer (as a "third party" or "third player") in a cooperative marketing or promotion planning process. The concept of including the third party, as the third "win" in a traditional "win-win" approach for cooperative marketing and promotion campaigns was presented for the first time in the marketing literature in 2009 (Spais, Papakonstantinidis \& Papakonstantinidis, 2009).

The 'win-win-win spais-papakonstantinidis-papakonstantinidis model' is a methodological tool for conflict resolution, especially in the case of decision-making, or in forming "instant reflection winning strategies" the BARGAIN (which is the frame) in vertical marketing channels for cooperative promotion management decisions. Marketing managers must realize that building a strong competitive advantage in a market mainly depends on the trust links among the partnerships in vertical marketing channels. Cohesion in the vertical marketing partnership in the marketing channel may be measured by the diversification Rate $\left(R^{*}\right)$ from strict rules: From this point of view, customers' intervention is useful, so as to diversify these "rules" at customized level adjusting them to their needs, wants, consuming identity, including communication codes, customs, ethics, culture. The "win-win-win spaispapakonstantinidis-papakonstantinidis model', as a vertical marketing channels' bargaining solution analysis for cooperative promotion management decisions can facilitate customers to "readjust" bargaining rules in each market, through a sensitization process: Community of customers is defined as a discrete spatial/cultural entity at its sensitization process' limit.

Future research tries may find see as a research challenge by examining the innovative bargaining solution analysis under different real case studies and under different assumptions. Quiet interesting could be an examination of the bargaining solution analysis by considering some of Kunter's (2012) assumptions in different market 
structure. For example: i) different per-unit cost of production for the members of the vertical marketing channel (excluding the customer); and ii) demand which retail price and non-price marketing effort on players/parties A and B simultaneously affect.

\section{CONCLUSION}

The basic initial assumption of this study is that different problems met in cooperative promotion planning requires adjusted bargaining solution analyses based on the win-win-win approach (including the "third win" for customers) and should not based on the traditional win-win.

The research intention was to examine the possibility to investigate win-win-win papakonstantinidis model in order to develop an integrated bargaining solution analysis for vertical cooperative sales promotion campaigns. Based on previous theoretical extensions (Spais and Papakonstantinidis, 2011; Spais, Papakonstantinidis and Papakonstantinidis, 2009), this study presented an integrated bargaining solution analysis for cases of optimal allocation of a promotion budget in a cooperative sales promotion campaign in vertical marketing channels. This integrated bargaining solution analysis included: a) three (3) adjusted utility functions, considering the parameters of sales response budgeting method, the break-even sales analysis and the marketing channel member's trade promotion goals; b) the referee solution, the optimal solution for the "three players" and the constraints; c) the definition of the third win in terms of a continuous sensitization process and perfect information; and d) presentation of the potential outputs from a bargaining process regarding to the sharing of the cooperative sales promotion cost among "A", "B" and "C" parties/players for different sales promotion offerings.

Based on the assumptions of the 'win-win-win papakonstantinidis' conceptualization, the limitation in contexts such as the cooperative promotion programs, is that utility assessment and cost-utility analyses such as costs/quality-adjusted expected profits model from the partnership for A and B parties/players and the C party/player (for customers/consumers) are frequently presented to demonstrate the value of many utility options in the marketing literature. The "C" party/player produces a new behavioral type that converges the interests of both sides. By converting, a binomial distribution (p, 1-p) into a trinomial distribution, (p1, p2 and 1-p1-p2) combined with three utility function "prices". However, utility indicators require various methods that introduce significant methodological challenges, which directly influence the results and ensuing cooperative promotion management decisions in vertical marketing channels. Encouragingly, the review of the modern literature and the critical case study confirmed the need for a win-win-win approach in cooperative sales promotion planning in vertical marketing channels.

\section{AUTHOR INFORMATION}

George S. Spais (Ph.D., Panteion University of Social \& Political Sciences, Greece) is an Adjunct Assistant Professor of the Higher Technological Educational Institute of Patras (Greece) and part-time educational personnel member ("SEP") of Hellenic Open University (Greece). He has been named an Associate Research Fellow at Euromed Research Business Institute (EMRBI) and he has been appointed as a member of the Board of Directors of the Clute Institute for Academic Research (Colorado, USA). He serves as a marketing co-editor of the Journal of Applied Business Research and as a member on the editorial boards of (in alphabetical order) Asian Journal of Marketing, Innovative Marketing, International Journal of Integrated Marketing Communications, International Review of Management, Journal of Business Case Studies, Journal of Marketing Education and Journal of Promotion Management. He is acting as an ad hoc reviewer for several international academic journals of marketing and academic conferences. He is an elected Member of the Chartered Institute of Marketing (MCIM). He is a member of the Academy of Marketing Science (USA), the European Marketing Academy of the European Institute for Advanced Studies in Management (Belgium), the Marketing Academy (UK), the EuroMed Academy of Business of the EuroMed Research Business Institute (Cyprus), the Greek Marketing Academy (Greece) and the Hellenic Institute of Marketing (Greece). E-mail: gspais@ otenet.gr 


\section{REFERENCES}

1. Ailawadi, K. (2001), The retail power-performance conundrum: What have we learned?. Journal of Retailing, 77(3), 299-318.

2. Ailawadi, K., Beauchamp, J., Donthu, N., Gauri, D. \& Shankar, V. (2009). Communication and promotion decisions in retailing: A review and directions for future research. Journal of Retailing, 85(1), 42-55.

3. Akanbi, P. \& Adeyeye, T. (2011). The association between advertising and sales volume: A case study of Nigerian Bottling Company plc. Journal of Emerging Trends in Economics and Management Sciences, 2(2), 117-123. Available: http://jetems.scholarlinkresearch.org/articles/The\%20Association\%20between\%20Advertising\%20and\%20 Sales\%20Volume.\%20A\%20Case\%20Study\%20of\%20Nigerian\%20Bottling\%20Company\%20Plc.pdf

4. Alam, I. (2002). An exploratory investigation of user involvement in new service development. Journal of the Academy of Marketing Science, 30(3), 250-261.

5. Albadvi, A. \& Koosha, H. (2011). A robust optimization approach to allocation of marketing budgets. Management Decision, 49(4), 601 - 621.

6. Arrow, K. \& Debreu, G. (1954). Existence of an equilibrium for a competitive economy. Econometrica, 22(3), 265-290.

7. Aumann, R. (1987). Game Theory. In: J. Eatwell, M. Milgate and \& Newman (eds.) The New Palgrave: Game Theory. New York: MacMillan/Norton.

8. Awa, H. (2010). Democratizing the new product development process: A new dimension of value creation and marketing concept. International Business Research, 3(2), 49-59.

9. Bazini, E. (2008). Marketing importance in consumer behaviour in the Albanian domestic tourism. Proceedings of the $1^{\text {st }}$ Euromed Conference, 29-39. Available: http://www.emrbi.com/photos/uploads/EuroMed_Conference_Proceedings\%5B2\%5D.pdf

10. Besanko, D., Dubé, J. \& Gupta, S. (2005). Own-brand and cross-brand retail pass-through. Marketing Science, 24(1), 110-122.

11. Bontems, P., Dhar, T. \& Chavas, J. (2007). Role of bargaining in marketing channel games of quality choice and profit share. Working Paper Series FSWP 2007-02 Food System Research Group, University of Wisconsin-Madison Available: http://www.aae.wisc.edu/fsrg/publications/wp2007-02.pdf

12. Bowen, D. (1986). Managing customers as human resources in service organizations. Human Resource Management, 25(3), 371-383.

13. Cannondale Associates (2003). The strategic role of trade: A case of consumer-based trade strategy. 2003 Industry study on trade promotion spending and merchandising. Evanston, IL: Cannondale Associates Inc.

14. Chen, X. \& Lu, R. (2007). Study on service innovation with employee and customer involvement — based on service profit chain”, 2007 Proceedings of International Conference on Enterprise and Management Innovation, 946-950.

Available:http://www.seiofbluemountain.com/upload/product/200911/2007qyczhy5z4a3.pdf

15. Chun, Y. \& Thomson, W. (1990). Bargaining with uncertain disagreement points. Econometrica, 58(4), 951-959.

16. Coughlan, A., Anderson, E., Stern, L. \& El-Ansary, A. (2001). Marketing Channels, 6th ed. Englewood Cliffs, NJ: Prentice Hall.

17. Crawford, V. (1997). Theory and Experiment in the Analysis of Strategic Interaction. In: D. Kreps K. Wallis (eds.), Advances in Economics and Econometrics: Theory and Applications (pp.206-242), Seventh World Congress 1, Cambridge University Press.

18. Cutler, A. (2004). Methodical failure: the use of case study method by public relations researchers. Public Relations Review, 30(3), 365-375.

19. Dabholkar, P. (1990). How to improve perceived service quality by improving customer participation. In: B. J. Dunlap (ed.), Developments in Marketing Science XIII, (pp.483-487), Cullowhee, NC: Academy of Marketing Science.

20. Dant, R. \& Berger, P. (1996). Modelling cooperative advertising decisions in franchising". Journal of the Operational Research Society, 47(9), 1120-1136.

21. Draganska, M., Klapper D. \& Villas-Boas, S. (2010). A larger slice or a larger pie? An empirical investigation of bargaining power in the distribution channel. Marketing Science, 29(1), 57-74. 
22. Drèze, X. \& Bell, D. (2003). Creating win-win trade promotions: Theory and empirical analysis of scanback trade deals. Marketing Science, 22(1), 16-39.

23. Du, R., Hu, Q. \& Ai, S. (2007). Stochastic optimal budget decision for advertising considering uncertain sales responses. European Journal of Operational Research, 183(3), 1042-1054.

24. Elmazi, L. \& Bazini, E. (2008). Marketing strategies for success of heritage attractions. Proceedings of the $1^{\text {st }}$ Euromed Conference, 203-211. Available: http://www.emrbi.com/photos/uploads/EuroMed_Conference_Proceedings\%5B2\%5D.pdf

25. Etgar, M. (2007). A descriptive model of the consumer co-production process. Journal of the Academy of Marketing Science, .36(1), 97-108.

26. Fang, E. (2008). Customer participation and the trade-off between new product innovativeness and speed to market. Journal of Marketing, 72(4), 90-104.

27. Flyvbjerg, B. (1991). Rationalitet og Makt (in Danish: Rationality and Power). Akademisk forlag.

28. Flyvbjerg, B. (2006). Five misunderstandings about case-study research. Qualitative Inquiry, 12(2), 219245. Available: http://flyvbjerg.plan.aau.dk/Publications2006/0604FIVEMISPUBL2006.pdf

29. Fu, Q. \& Zeng, S. (2008). Game analysis of cooperative advertising and ordering strategies in a supply chain under demand uncertainty. Xitong Gongcheng Lilun yu Shijian/System Engineering Theory and Practice, 28(3), 56-63.

30. Fux, M. Mathieu, D. \& Myrach, T. (2007). Cooperative customer relationship management (CRM) in Alpine tourist destinations. Proceedings of the 2007 European Conference of Information Systems (ECIS), 2307 - 2318. Available: http://is2.1se.ac.uk/asp/aspecis/20070057.pdf

31. Gabrielsena, T. \& Roth, S. (2009). Delegated bargaining in distribution channels. Australasian Marketing Journal, 17(3), 133-141.

32. Galbraith, J. (2005). Designing the customer-centric organization: A guide to strategy, structure and process. San Francisco: Jossey-Bass.

33. Geib, M., Kolbe, L. \& Brenner, W. (2005). Customer relationship management in business networks: Lessons from the financial services industry in Germany and Switzerland. MISQ Executive, 4(1), 247-260.

34. Gómez, M. \& Rao, V. (2009). Market power and trade promotions in US supermarkets", British Food Journal, 111(8), $866-877$.

35. Gómez, M., Rao, V. \& McLaughlin, E. (2007). Empirical analysis of budget and allocation of trade promotions in the U.S. supermarket industry. Journal of Marketing Research, 44(3), 410-424.

36. Harsanyi J. (1967). Games with incomplete information played by Bayesian players, I-III: Part I. The basic model. Management Science, 14(3), 159-182.

37. Harsanyi, J. (1973). Games with randomly disturbed payoffs. International Journal of Games Theory, 2(1), $1-23$.

38. He, X., Krishnamoorthy, A., Prasad, A. \& Sethi, S. (2011). Retail competition and cooperative advertising. Operations Research Letters, 39(1), 11-16.

39. He, X., Prasad, A. \& Sethi, S. (2009). Cooperative advertising and pricing in a dynamic stochastic supply chain: Feedback Stackelberg strategies. Production and Operations Management, 18(1), 78-94.

40. Hip, C. \& Grupp, H. (2005). Innovation in the service sector: The demand for service-specific innovation measurement concepts and typologies. Research Policy, 34(4), 517-535.

41. Hu, W., Jianyou, Z. \& Na, L. (2010). Research on the construction of grid marketing team", Proceedings of the 7th International Conference on Innovation \& Management, 856-860. Available: http://www.pucsp.br/icim/ingles/downloads/papers_2010/part_5/40_Research\%20on\%20the\%20Constructi on\%20of\%20Grid\%20Marketing\%20Team.pdf

42. Huang, X. \& Brown, A. (1999). An analysis and classification of problems in small business. International Small Business Journal, 18(1), 73-85.

43. Huang, Z., \& Li, S. (2001). Co-op advertising models in a manufacturer-retailer supply chain: A game theory approach. European Journal of Operational Research, 135(3), 527-544.

44. Huang, Z., Li, S. \& Mahajan, V. (2002). An analysis of manufacturer-retailer supply chain coordination in cooperative advertising. Decision Sciences, 33(3), 469-494.

45. Iyer, G. \& Villas-Boas, M. (2003). A bargaining theory of distribution channels. Journal of Marketing Research, 40(1), 80-100.

46. Johne, A., \& Storey, C. (1998). New service development: A review of the literature and annotated Bibliography. European Journal of Marketing, 32(3), 184-252. 
47. Kohlbacher, F. (2006). The use of qualitative content analysis in case study research. Forum Qualitative Sozialforschung / Forum: Qualitative Social Research, 7(1). Available: http://www.qualitativeresearch.net/index.php/fqs/article/view/75/154

48. Kumar, N., Rajiv, S. \& Jeuland, A. (2001). Effectiveness of trade promotions: Analyzing the determinants of retail pass through. Marketing Science, 20(4), 382-404.

49. Kunter, M. (2012). Coordination via cost and revenue sharing in manufacturer-retailer channels. European Journal of Operational Research, 216(2), 477-486.

50. Li, S. Huang, Z., Zhu, J. \& Chau, P. (2002). Cooperative advertising, game theory and manufacturerretailer supply chains. Omega, 30(5), 347-357.

51. Little, J. (2004). Models and managers: The concept of a decision calculus. Management Science, 50(12), 1841-1853. Available: http://cursos.puc.cl/eaa333a-1/almacen/1299095561_pmarshall_sec1_pos0.pdf

52. Lovelock, C. \& Young, R. (1979). Look to consumers to increase productivity. Harvard Business Review, 57(3), 168-178.

53. Lusch, R., Vargo, S. \& O’Brien, M. (2007). Competing through service: Insights from service-dominant logic. Journal of Retailing, 83(1), 5-18.

54. Luxton, S., Hodge, C. \& Reid, M. (2002). Examining the relevance of IMC in the Australian SME context", Proceedings of the 2002 ANZMAC Conference, 1721-1726. Available: http://smib.vuw.ac.nz:8081/WWW/ANZMAC2002/papers/pdfs/p200_luxton.pdf

55. Merzenich, M. (2005). Prozessmanagement im Customer Relationship Management - Gestaltung und Implementierung kundenorientierter Geschäftsprozesse. Berlin: Logos Verlag.

56. Miller, N. \& Pazgal, A. (2007). Advertising budgets in competitive environments. Quantitative Marketing and Economics, 5(2), 131-161.

57. Misra, S. \& Mohanty, S. (2008). Estimating bargaining games in distribution channels. Available: http://www.simon.rochester.edu/fac/misra/bargaining.pdf

58. Morton, F. \& Zettelmeyer, F. (2000). The strategic positioning of store brands in retailer - manufacturer bargaining. NBER Working Paper No.7712. Available: http://www.nber.org/papers/w7712.pdf

59. Muthoo, A. (1999). Bargaining theory with applications. Cambridge: Cambridge University Press.

60. Nagler, M. (2006). An exploratory analysis of the determinants of cooperative advertising participation rates. Marketing Letters, 17(2), 91-102.

61. Naik, P., Raman, K. \& Winer, R. (2005). Planning marketing-mix strategies in the presence of interaction effects. Marketing Science, 24(1), 25-34.

62. Nash, J. (1950). The bargaining problem. Econometrica, 18(2), 155-162.

63. Nash, J. (1951). Non co-operative game, Princeton,, NJ.: Princeton University Press.

64. Nash, J., Nasar, S. \& Kuhn, H. (2001). The essential John Nash, Princeton,, NJ.: Princeton University Press.

65. Paik, S. \& Bagchi, P. (2007). Understanding the causes of the bullwhip effect in a supply chain. International Journal of Retail \& Distribution Management, 35(4), 308-324.

66. Palmer, A. \& Mccole, P. (2000). The role of electronic commerce in creating virtual tourism destination marketing organisations. International Journal of Contemporary Hospitality Management, 12(3), 198-204.

67. Papakonstantinidis, L. (2002). The Sensitized Community. Athens: Typothito Edition.

68. Papakonstantinidis, L. (2003). Rural tourism: Win-win-win- case study women cooperative Gargaliani. Journal of Hospitality and Tourism, 1(2), 49-70.

69. Papakonstantinidis, L. (2004a). Sensitization as a form of knowledge creation and the win-win-win Model. Scientific Review of Applied Research, 8(2), 89-108.

70. Papakonstantinidis L. (2004b). Sensitization and involving the community. A rural development application of the win-win-win model. Scientific Review of Economic Sciences, 6, 177-192

71. Papakonstantinidis, L. (2007). Win-win-win methodology on rural tourism activities: Good practices from Greece. Asian Journal of Hospitality and Tourism, 1(1), 95-120.

72. Papakonstantinidis, L. (2011). The intermediate community: A behavioral/bargaining approach for conflict resolution at the local level - Bayesian analysis. Proceedings of the $4^{\text {th }}$ Annual Euromed Conference of the Euromed Academy of Business, 1443-1456.

73. Papasolomou, I. \& Demetriou, M. (2008). The complementary nature of cause related marketing and international marketing. Proceedings of the $1^{\text {st }}$ Euromed Conference, 739-740. Available: http://www.emrbi.com/photos/uploads/EuroMed_Conference_Proceedings\%5B2\%5D.pdf 
74. Payne, A., Storbacka, K. \& Frow, P. (2008). Managing the co-creation of value. Journal of the Academy of Marketing Science, 36(1), 83-96.

75. Piller, F. (2005). Mass customization: Reflections on the state of the concept. International Journal of Flexible Manufacturing Systems, 16(4), 313-334.

76. Roma, P. \& Perrone, G. (2010). Generic advertising, brand advertising and price competition: An analysis of free-riding effects and coordination mechanisms. Review of Marketing Science, 8, Article 4. Available: http://www.bepress.com/romsjournal/vol8/iss1/art4

77. Scheffman, D. (2002). Antitrust economics and marketing. Journal of Public Policy \& Marketing, 21(2), 243-246.

78. Schumacher, J. \& Meyer, M. (2004). Customer relationship management strukturiert dargestellt. Berlin/Heidelberg: Springer.

79. Sethi, P. (1983). Deterministic and stochastic optimization of a dynamic advertising model. Optimal Control Application and Methods, 4(2), 179-184.

80. Seyedesfahani, M., Biazaran, M. \& Gharakhani, M. (2011). A game theoretic approach to coordinate pricing and vertical co-op advertising in manufacturer-retailer supply chains. European Journal of Operational Research, 211(2), 263-273.

81. Sheth, J., Sisodia, R. \& Sharma, A. (2000). The antecedents and consequences of customer-centric marketing. Journal of the Academy of Marketing Science, 28(1), 55-66.

82. Siguaw, J. \& Enz, C. (1999). Best practices in information technology. Cornell Hotel and Restaurant Administration Quarterly, 40(5), 58-71.

83. Sigué, S. (2008). Consumer and retailer promotions: Who is better off?. Journal of Retailing, 84(4), 449460.

84. Sorger, G. (1989). Competitive dynamic advertising: A modification of the case game. Journal of Economic Dynamics and Control, 13(1), 55-80.

85. Spais, G. (2010). Search Engine Optimization (SEO) as a dynamic online promotion technique: The implications of activity theory for promotion managers. Innovative Marketing, 6(1), 7-24.

86. Spais, G. (2011). An activity system as a behavioristic framework for the elaboration of promotion techniques. Journal of Applied Business Research, 27(3), 9-32.

87. Spais, G., Papakonstantinidis, L. \& Papakonstantinidis, S. (2009). An innovative bargaining solution analysis for vertical cooperative promotion management decisions. Innovative Marketing, 5(3), 7-29.

88. Spais, G. \& Papakonstantinidis, L. (2011). An application of the win-win-win papakonstantinidis model as an innovative bargaining solution analysis in cooperative sales promotion campaigns. Proceedings of the $4^{\text {th }}$ Annual Euromed Conference of the Euromed Academy of Business, 1724-1744.

89. Sriram, S. \& Kalwani, M. (2007). Optimal advertising and promotion budgets in dynamic markets with brand equity as a mediating variable. Management Science, 53(1), 46-60.

90. Stake, R. (1994). Case Studies. In: N. Denzin \& Y. Lincoln (eds.) Handbook of Qualitative Research. Thousand Oaks, CA: Sage Publications.

91. Stet, M. (2008). Demand amplification map and distortions in supply chains. Annals of the Oradea University, Fascicle of Management and Technological Engineering, 7, .2772-2777. Available: http://imtuoradea.ro/auo.fmte/files-2008/MIE_files/STET\%20MIHAELA\%201.pdf

92. Sullivan, M. (2002). The role of marketing in antirust. Journal of Public Policy \& Marketing, 21(2), 247249.

93. Sundbo, J. (1997). Management of innovation in services. The Service Industry Journal, 17(3), 432-455.

94. Thrassou, A. \& Vrontis, D. (2006). A small services firm marketing communications model for SMEdominated environments. Journal of Marketing Communications, 12(3), 183-202.

95. Tsiotsou, R., Rigopoulou, I. \& Kehagias, I. (2010). Tracing customer orientation and marketing capabilities through retailers' websites: A strategic approach to internet marketing. Journal of Targeting, Measurement \& Analysis for Marketing, 18(2), 79-94.

96. Tyagi, R. (1999). A Characterization of retailer response to manufacturer trade deals. Journal of Marketing Research, 36(4), 510-516.

97. Uden, L., Valders, P. \& Pastor, O. (2008). An activity-theory-based model to analyse web application requirementsl. Information Research, 13(2). Available: http://informationr.net/ir/13-2/paper340.html.

98. Varoufakis, Y. (2001). Game theory: Critical perspectives vol.I. London: Routledge. 
99. Vidale, M. \& Wolfe, H. (1957). An operations-research study of sales response to advertising. Operations Research, 5(3), 370-381.

100. Von Neuman, J. \& Morgenstern, O. (1947). Game Theory and Economic Behavior, Princeton, NJ: Princeton University Press.

101. Vrontis, D., Thrassou, A. \& Czinkota M. (2011). Wine marketing: A framework for consumer-centred planning. Journal of Brand Management, 18(4), 245-263.

102. Wikstrom, S. (1995). The consumer as co-producer. European Journal of Marketing, 30(4), 6-19.

103. Williams, A. \& Palmer, A. (1999). Tourism destination brands and electronic commerce: Towards synergy? Journal of Vacation Marketing, 5(3), 263-275.

104. Wind, Y. \& Rangaswamy, A. (2001). Customerization: The next revolution in mass customization. Journal of Interactive Marketing, 15(1), 13-32.

105. Xie, J. \& Wei, J. (2009). Coordinating advertising and pricing in a manufacturer-retailer channel. European Journal of Operational Research, 197(2), 785 - 791.

106. Yan, R. (2010). Cooperative advertising, pricing strategy and firm performance in the e-marketing age. Journal of the Academy of Marketing Science, 38(4), 510-519.

107. Yin, R. (1994). Case study research: Design and methods (2nd ed.). Thousand Oaks, CA: Sage Publications.

108. Youngdahl, W. \& Kellogg, D. (1997). The relationships between service customers' quality assurance behaviors, satisfaction, and effort: A cost of quality perspective. Journal of Operations Management, 15(1), 19-32.

109. Yue, J., Austin, J., Wang, M. \& Huang, Z. (2006). Coordination of cooperative advertising in a two-level supply chain when manufacturer offers discount. European Journal of Operational Research, 168(1), 6585 .

110. Zhuang, G., Herndon, N. \& Zhou, N. (2005). Power usage in marketing channels given the conditions of power advantage versus power disadvantage. 2005 Proceedings of the Australian and New Zealand Marketing Academy Conference, 83-90. 
NOTES 